\title{
Sanción al plagio de obras literarias en el Instituto Nacional de Defensa de la Competencia y de la Protección de la Propiedad Intelectual (Indecopi) en Perú *
}

\author{
Rosalía Quiroz Papa de García **
}

Artículo recibido:

15 de enero de 2013.

Artículo aceptado:

28 de octubre de 2013.

\section{Resumen}

La investigación describe y analiza la jurisprudencia del Tribunal de Indecopi, que a través de la Sala de Propiedad Intelectual emite sus resoluciones en segunda y última instancia administrativa en Perú. El estudio se realizó con base en las resoluciones sobre casos de infracción a los derechos morales del autor en su modalidad de plagio, las mismas que se encuentran en la página web de la institución. El periodo objeto de análisis comprende los años 2008-2011. La metodología empleada ha sido básicamente el análisis documental, teniendo a la vista cada una de las resoluciones emitidas por la Sala que resuelven las causas de infracción al derecho de autor. En conclusión, no obstante que la

Investigación llevada a cabo con apoyo económico del Vice Rectorado de Investigación-Consejo Superior de Investigaciones.

** Universidad Nacional Mayor de San Marcos, Perú. rosaliaqp@yahoo.com

INVESTIGACIÓN BIBLIOTECOLÓGICA, Vol. 28, Núm. 63, mayo/agosto, 2014, México, ISSN: 0187-358X. pp. 115-162 
figura del plagio se ha extendido con la aparición de Internet, las denuncias son muy escasas, la mayoría son formalizadas por denuncia de oficio a partir de la función que ejerce la entidad competente encargada de velar por la protección a la propiedad intelectual.

Palabras clave: Ética; Plagio; Propiedad intelectual; Derecho de autor.

\section{Abstract}

Penalties for plagiarism of literary works imposed by Peru's Instituto Nacional de Defensa de la Competencia y de la Protección de la Propiedad Intelectual (Indecopi) (National Institute of Jurisdiction and Protection of Intellectual Property)

Rosalia Quiroz-Papa de García

The research describes and analyzes the jurisprudence of the Court of Indecopi, which through the Chamber of Intellectual Property issues rulings as the second and final administrative authority in Peru. This study examined rulings handed down over a four-year period (2008-211) in copyright infringement cases, i.e., plagiarism, which, moreover, appear on the web page of the institution. The study employs a documentary analysis methodology of each plagiarism case ruling issued by the Chamber. Notwithstanding the relatively scant number of plagiarism cases arising from online publishing, the study concludes that the legal conception of plagiarism has expanded since the advent of the internet. Most of these cases are filed and pursued ex officio by the office charged with protecting intellectual property and copyright.

Keywords: Ethics; Plagiarism; Intellectual property; Copyright.

\section{INTRODUCCIÓN}


en el mundo académico, entre las cuales tenemos el plagio, el fraude, la piratería, que atentan contra la ciencia, el arte y la técnica.

Aun cuando la deshonestidad académica entre el alumnado está documentada desde muy antiguo, no fue sino hasta la década de los noventa del siglo pasado cuando se inició su estudio de forma sistemática, con el objetivo de combatir el fenómeno del plagio académico, que en aquellos años ya empezaba a ser alarmante (Sureda, Comas y Morey, 2009: 1989).

Las causas son diversas, una de las más importantes es el avance de las nuevas tecnologías de la información y la comunicación, en particular de Internet, que han traído consigo la explosión y abundancia de fuentes de información, además de las facilidades que ofrece el hecho de disponer en tiempo real de artículos de texto completo en revistas, proyectos, tesis, monografías, libros y bases de datos, entre otros materiales. Otra causa es la crisis de valores morales por la que atraviesa la sociedad en su conjunto, que se refleja en conductas deshonestas en todo tipo de actividades, una de las cuales es precisamente la actividad académica, al no respetar la propiedad intelectual, recurriendo al plagio sin el mínimo atisbo de remordimiento, de modo que numerosos estudios dan cuenta del robo de la creación ajena, lo que se ha convertido en una conducta cada vez más extendida, hasta el punto de llamar a ésta la generación del "copiar y pegar". Para Carmona "El plagio es un fraude doloso contra la producción literaria, artística o científica de un autor, en la que basándose en una creación precedente, una persona se adjudica como propios trabajos de otros" (1988: 315).

La realidad del Perú no es ajena a esta problemática, se observa un alto grado de permisividad e impunidad en todas las esferas de la sociedad y existe una manifiesta inoperancia, particularmente en las instituciones de educación superior, por la casi nula sanción que imponen al considerar a este tipo de conductas como una falta leve, mas no en su verdadera dimensión de delito que atenta contra la comunidad académica. Sucede entonces que las autoridades hacen poco o casi nada por implementar medidas de sensibilización y prevención del plagio, y se desconoce el uso de herramientas tecnológicas modernas que permiten rastrear y comparar diferentes textos con documentos originales.

Rojas y Olarte señalan:

Importa, reiterar que el plagio, así entendido, constituye la vulneración simultánea de diferentes derechos morales y patrimoniales. La infracción al derecho moral del autor plagiado se configura respecto de su derecho de paternidad, pues el 
plagiario se hace pasar como autor de la obra de otra persona. De igual forma, es común que se lesione el derecho moral de integridad, pues con el propósito de disfrazar o de ocultar su acción ilegítima, el actor modifica o suprime apartes sustanciales de la obra a fin de hacerla pasar como una creación diferente de la originaria (2010: 2).

Este hecho nos lleva a plantear como objetivos de la investigación el identificar y analizar el procedimiento administrativo llevado a cabo en el Perú por el organismo estatal encargado de velar por la protección de la propiedad intelectual (Indecopi), en los casos de plagio de obras literarias, así como determinar el tipo de sanciones que durante los últimos cuatro años ha impuesto el Tribunal a través de sus resoluciones emitidas en última instancia. Para tal efecto, se ubicaron pormenorizadamente las jurisprudencias sobre infracción a los derechos morales del autor resueltas por la Sala de Propiedad Intelectual de Indecopi-Perú, las cuales se encuentran en la página web de la institución (Anexo 1). Con las resoluciones a la vista, se analizó cada una de ellas según una serie de variables e indicadores previamente establecidos a fin de cumplir con los objetivos del estudio. Los resultados obtenidos en el curso de la investigación indican que la mayor incidencia de las denuncias sobre infracción a los derechos morales corresponde a la infracción a la paternidad del autor bajo la modalidad del plagio burdo o servil, conducta que se manifiesta en el hurto o robo del contenido de obras ajenas. Las denuncias generalmente son formalizadas de oficio por las autoridades de la entidad competente, las sanciones pecuniarias impuestas en primera instancia son altas (más de 5 Unidades Impositivas Tributarias), pero fueron drásticamente reducidas en la segunda y última instancia.

\section{REVISIÓN DE LA LITERATURA}

\section{El plagio}

El plagio es el hurto de la creación intelectual ajena que se manifiesta en la usurpación de la paternidad del autor, modificando, divulgando o reproduciendo dicha creación como si fuera propia. En palabras de Cabanellas el plagio es: "En materia de propiedad literaria, científica o artística, la copia o imitación que no confiesa el modelo o el autor seguido (1976: 305). Para Saldaña, Quezada, Peña y Mayta "Se define plagio a la apropiación de las ideas, procesos o resultados, presentados en una publicación sin dar crédito al autor de la misma" (2010: 2). En tanto que Delgado considera: "Un apoderamiento ideal 
de una obra ajena, bien haciéndose pasar como propia, bien utilizando los elementos creativos de aquella para la elaboración de la creación ilegítima" (1988: 117).

En el ámbito de las obras literarias el plagio es la apropiación indebida de frases, oraciones, párrafos o textos completos sin citar la fuente ni darle crédito al autor.

Girón detalla algunas acciones que configuran el plagio literario:

- Copiar el trabajo total o parcial de otro estudiante (con autorización o sin ella).

- Copiar y pegar el contenido de artículos o páginas de Internet sin usar comillas y sin dar el nombre de la fuente consultada.

- No citar la fuente de donde se toma la información.

- Mover o reubicar de un texto unas pocas palabras o frases o cambiar el orden en el que ellas estaban originalmente.

- Copiar partes significativas de un texto o del trabajo de otro.

- No poder explicar o sustentar el contenido del escrito.

- Cuando se desarrollan pensamientos o teorías basadas en ideas ajenas, sin dar crédito a la persona sobre cuya idea se basa la discusión.

- Repetir o parafrasear palabras, ideas o argumentos de alguien sin otorgarle el debido reconocimiento.

- Comprar o adquirir un trabajo y presentarlo parcial o totalmente como propio (2008: 7).

Cabe añadir a lo anterior las definiciones contenidas en las resoluciones de tribunales nacionales e internacionales al fundamentar sus fallos, además de las que corresponden a la legislación comunitaria y a otros organismos y que se mencionan a continuación.

El Tribunal de Justicia de la Comunidad Andina de Naciones (CAN), citado por Astudillo, define en el Proceso 139-IP-2003:

Por plagio hay que entender en su acepción más simplista, todo aquello que supone copiar obras ajenas en lo sustancial, presentándolas como propias. Se trata de una acción material de muy poco o ningún contenido intelectual, carente de originalidad (2006: 244).

\section{Agrega el autor:}

En una decisión anterior señaló el mismo Tribunal: "A tales efectos, se entiende por plagio '[...] el acto de ofrecer o presentar como propia, en su totalidad o en parte, la obra de otra persona, en una forma o contexto más o menos alterados [...]'” (Proceso 10-IP-99) (Astudillo, 2006: 244). 
Balbuena también cita algunas jurisprudencias en las que se define el plagio:

La jurisprudencia de fecha 27 de abril de 1978 del Tribunal Supremo Español señaló que: Hay plagio cuando se suprime y prescinde del creador de la obra poniendo a otro en su lugar, siendo la persona más que la cosa que sufre el atentado perpetrado por el plagiario, al ser esa personalidad la que desaparece, permaneciendo la obra más o menos incólume. La sentencia de fecha 13 de febrero de 1984, el alto tribunal de España sostuvo: También hay plagio cuando se trata de copiar la idea original o auténtica de una manera servil o falsificada de forma que induzca a error sobre la autenticidad o imitación, haciéndolo de modo parcial o total, y efectuando una suplantación para presentar como propia una obra ajena y aprovecharse de la firma inédita e intelectual de su autor (s. a.: 4).

En esta misma línea el Indecopi, entidad estatal en el Perú encargada de velar por la protección a la propiedad intelectual, a través de una de las jurisprudencias del Tribunal recaída en la Resolución Núm. 1266-2008/TPI-. Expediente Núm. 81-2007/ODA de fecha 29 de mayo de 2008, reproduce la cita de Valbuena sobre el plagio, quien hace referencia a los autores Delgado, Quintano y García:

El plagio es entendido por la doctrina como el apoderamiento de todos o de algunos elementos originales contenidos en la obra de otro autor, presentándolos como propios, ya sea haciendo pasar la obra como propia o bien utilizando los elementos creativos de aquélla para la elaboración de la obra ilegítima. En ambos casos se prescinde de la paternidad del autor sobre la obra preexistente y de su autorización, resultando ser el delito capital en materia de derecho de autor. A través de esta conducta el plagiario se aprovecha de la labor creadora de otro, para lo cual copia sustancialmente la obra y aparenta ser su auténtico creador (Indecopi, Resolución Núm. 1266-2008/TPI:5).

Para la Organización Mundial de la Propiedad Intelectual (OMPI) el plagio es: "El acto de ofrecer o presentar como propia, en su totalidad o en parte, una obra de una persona en una forma o contexto más o menos alterado" (1988: 182). La Pontificia Universidad Católica del Perú (PUCP) señala en su página web (http://www.pucp.edu.pe): "El plagio consiste en hacer pasar como nuestras ideas, los textos que pensaron otros y que nos fueron transmitidos por ellos, bien por escrito, bien oralmente o por algún otro mecanismo de comunicación".

Al decir del Cuerpo Académico de Ética de la Universidad Autónoma del Estado de Morelos: 
El plagio es el hecho de copiar o imitar fraudulentamente una obra ajena, particularmente, una obra literaria o artística. Es una falta moral que puede llegar a ser grave dadas las condiciones que envuelven el caso: la importancia de la persona que plagia, la calidad del documento plagiado, la dificultad de reconocerlo, la cantidad de material plagiado son varias de las circunstancias que darán al plagio la medida de su gravedad. En el medio educativo, escuelas primarias y hasta universidad, el plagio siempre es grave porque va precisamente contra una de las normas que dan la esencia a la educación: la búsqueda de la verdad y de la justicia, porque roba ideas, imágenes, proyecto a otro. Esta dimensión es desconocida por muchos que ven en esta práctica una falta menor que se justifica sencillamente. Es importante mostrar, instruir y educar para que el plagio sea desterrado de las malas prácticas de la vida estudiantil (UAEM, 2002: 1).

Tal como se advierte en las definiciones anteriores, el plagio es la conducta que infringe deliberadamente los derechos morales del autor, usurpando la paternidad, modificando o alterando la integridad de su obra. En la configuración del plagio están presentes tres elementos: el plagiario, persona natural con una conducta ilícita e inmoral manifiesta; el autor, cuyos derechos morales han sido vulnerados, y la obra objeto del plagio.

\section{Origen}

La literatura da cuenta que los orígenes del plagio se remontan a la época antigua, desde que se plasma en una obra la creación de los primeros pensadores, llámense filósofos, poetas o matemáticos, además de artistas y pintores. Así lo anota Astudillo: "Se señala al poeta latino Marcus Valerius Martialis, como la primera persona en utilizar el término plagio en sentido figurado para referirse a la apropiación de frases ajenas (L'Enciclopédie de L'Agora, s.f. p. s(n)” (2006: 245-246).

Las investigaciones efectuadas por Perromat en su tesis doctoral también corroboran que el plagio data de épocas muy antiguas, incluso los filósofos más destacados de entonces, como Platón, Aristóteles y otros, fueron acusados de robo o apropiación de obras ajenas:

Platón, en una conocida anécdota que circuló en la Antigüedad en diferentes versiones, fue acusado de plagiar al mismo Pitágoras, después de haber adquirido un texto de Filolao (discípulo de aquél) mediante el pago de diez mil denarios. Aulo Gelio, en el siglo II, reprodujo en sus Noches Áticas los siguientes versos de Timón: "Tú, Platón, puesto que ansiabas el saber,/ por una suma desorbitada compraste un librito/ que te enseñó a escribir el Timeo".

La amplia difusión de estas acusaciones nos ha dejado algunos ejemplos en los textos griegos conservados. De este modo, también Teopompo de Quíos en su obra La escuela de Platón, afirma que: "[s]e descubrirá que la mayoría de sus 
diálogos son inútiles y falsos: la mayoría plagios, procedentes de las diatribas de Aristipo y algunos, incluso, de las de Antístenes y muchos de las de Brisón de Heraclea".

Estas acusaciones también se extendieron a Aristóteles, y dan una idea aproximada sobre la consolidación de una figura de autor (una función específica de los nombres propios que acompañan a los textos), y la resistencia ejercida por diferentes autores frente a las obras percibidas como discordantes con este paradigma hermenéutico. El hecho de que en estas acusaciones se entremezclen objetivos políticos o ideológicos con apreciaciones literarias no invalida las hipótesis de un origen antiguo de la relación Autor-Texto, o si se prefiere de la Función-Autor como máxima garantía de coherencia y autenticidad textual (2010: 29).

Otros autores sostienen que la figura del plagio, como apropiación de la obra ajena, aparece en el siglo XV con la imprenta móvil de Gutenberg, que hizo posible la aparición de obras impresas de diferentes autores y con ello la expansión cultural y la democratización del libro, gracias a su amplia difusión entre los diferentes sectores de la población. Busta lo refiere así:

En la antigüedad la producción literaria y artística no tuvo gran desarrollo, sin embargo, la iglesia cristiana tuvo la más brillante producción y la protegían de las hordas bárbaras. Más adelante, en el Renacimiento, las creaciones fueron bastante fructíferas en el campo de la pintura, escultura, arquitectura y otras artes, pero debido a la carencia de normas muchos autores y artistas quedaron en la miseria y el olvido. El descubrimiento de la imprenta originó la creación de los privilegios Reales o Regalía. Estas figuras nacieron con el objeto de evitar la libre circulación de las ideas mediante la censura previa, prohibiéndose la reproducción y venta de las obras sin el permiso del soberano. Asimismo, se estableció la posibilidad de reproducir obras literarias masivamente, iniciándose con ello la protección de las creaciones del intelecto a través de los privilegios (1997:32-33).

Luego de este breve recorrido histórico sobre los orígenes del plagio, se puede decir que el reconocimiento y la sistematización legal de las creaciones de la mente surgen en el siglo XVIII con las primeras leyes de protección al derecho de autor. Es así que en Inglaterra (1710) se aprueba la norma denominada El Estatuto de la Reina Ana (Statute of Anne), que regulaba la actividad de los autores y editores y ponía fin al monopolio de estos últimos, los llamados "privilegios reales". A partir de entonces se les otorgó a los autores la titularidad exclusiva sobre sus obras, y además el derecho de autorizar la impresión de copias, inicialmente por un tiempo de 14 años renovables a otros 14, y los obligaba a depositar nueve ejemplares para universidades y bibliotecas.

Es importante resaltar que en 1813 la Corte de Cádiz introdujo en el campo del derecho de autor la figura del dominio público sobre las obras 
literarias, que no era más que el derecho de la sociedad a acceder a la información y a la cultura en general, reproduciendo o comunicando las obras sin previo consentimiento del autor o sus derechohabientes, pero siempre reconociéndole su autoría o paternidad. La Corte autorizó la reproducción de las obras una vez transcurridos 10 años de la muerte del autor y sin el consentimiento expreso de los herederos. Actualmente, de acuerdo con el Convenio de Berna (1886) el plazo mínimo de protección es de 50 años, el cual se extendió más adelante en diversos países hasta los 100 años, antes de que la obra ingrese al dominio público. En el Perú el plazo es de 70 años, en Colombia es de 80 años y en México de 100 años.

\section{Requisitos en la configuración del plagio}

Puesto que el plagio es una conducta ilícita e inmoral del plagiario, para su real identificación y tipificación es fundamental que concurran una serie de elementos que necesariamente deben estar presentes en el hecho.

\section{La obra}

El Dec. Leg. Núm. 822 de 1996, Art. 2.17, ofrece la definición siguiente: "Obra: es toda creación intelectual personal y original, susceptible de ser divulgada o reproducida en cualquier forma conocida o por conocerse". Lipszyc considera que "Para el derecho de autor, obra es la expresión personal de la inteligencia que desarrolla un pensamiento que se manifiesta bajo una forma perceptible, tiene originalidad o individualidad suficiente, y es apta para ser difundida y reproducida" (1993: 61). Desde luego, para que se dé la figura del plagio es necesario que previamente exista la obra producto de la creación del autor. De no demostrarse su preexistencia, carecería de sustento tipificar una conducta como plagio.

El autor

El Art. 2.1 del decreto mencionado señala lo siguiente: "Autor: persona natural que realiza la creación intelectual”. Es requisito la presencia del autor, quien es el único que tiene la titularidad originaria con derechos morales sobre la obra de su creación. Cabe anotar que la norma distingue dos tipos de titularidad, la originaria y la derivada.

- Art. 2.44. Titularidad originaria: La que emana de la sola creación de la obra, sólo la tiene el autor. 
- Art. 2.44. Titularidad derivada: La que surge por circunstancias distintas de la creación, sea por mandato o presunción legal, o bien por cesión mediante acto entre vivos o transmisión mortis causa.

Falta de consentimiento del autor

El autor es el único que tiene la facultad de autorizar el uso de su obra; forma parte de sus derechos morales, que son exclusivos, irrenunciables, inembargables e imprescriptibles. Consecuentemente, una característica del plagio es que se produce por la falta de autorización del autor.

La conducta ilícita

El plagiario siempre será una persona natural, cuya conducta ilícita o contraria a la ley debe ser manifiesta, objetiva y demostrable. Debe presentarse la acción de copiar, reproducir o imitar total o parcialmente frases, oraciones, párrafos o la integridad del contenido de una obra literaria, suplantando la paternidad y sin dar crédito al autor ni citar la fuente. Esta condición es básica para que se ajuste al derecho y al principio jurídico, puesto que la tipificación de la conducta sólo la debe hacer la ley con anterioridad a la infracción, de allí la frase latina nullum crimen, nullum poena sine lege (no existe crimen ni pena sin ley).

\section{Falta de originalidad}

Uno de los elementos en el contenido de una obra es la originalidad del autor, entendida ésta como la manifestación clara e inequívoca de su personalidad.

El Indecopi establece en su Resolución Núm. 286-1998-TPI-.P.4.4 que:

Si bien toda obra es el producto del esfuerzo de su creador, no todo lo producido con esfuerzo merece protección por derechos de autor. Ello sólo será posible en la medida que la creación tenga elementos de originalidad suficientes para ser considerada como obra. Admitir lo contrario, implicaría proteger incluso aquello que no es objeto de protección por derechos de autor, como la elaboración de la lista de películas que se exhiben en los cines de Lima. El requisito de originalidad o individualidad implica que para la creación de la obra debe existir un espacio para el desarrollo de la personalidad de su autor. En consecuencia, lo que ya forma parte del patrimonio cultural -artístico, científico o literario- no puede ser individual. Igualmente, la originalidad sirve para diferenciar las obras protegidas por derechos de autor de las banales, de la vida diaria, rutinarias. 
Abundando en el tema, Lipszyc señala que concurren otros requisitos en el plagio: "a. Usurpar la paternidad de una obra. b. Transformar la obra. c. Divulgar la obra plagiada [...]. d. Actuar con dolo, con mala fe, con intencionalidad, y tener conciencia que la obra que plagia no es suya sino de terceros, a esto se le llama '[...] la ajeneidad de la obra como elemento de suficiencia para configurar el dolo [...]' " (citada en Balbuena, s. a.: 11-13). En efecto, es de advertir que la presencia de estos elementos en la configuración del plagio excluye a otros, como el valor de la obra, el contenido, la extensión, la finalidad para la que hubiera sido creada, el soporte sobre el que recae el contenido, así como la comercialización o no; basta que se produzca la vulneración del bien jurídico tutelado para exigir su sanción, al margen de otras consideraciones que sirven de justificación al plagiario. Por tanto, no se puede dejar de observar el principio universal del derecho que la ignorancia de la ley no impide su sanción y tampoco exime su cumplimiento.

Las leyes son de estricto cumplimiento a partir del día siguiente de su publicación, salvo disposición en contrario, por lo que se presume conocida por todos, es más, no corresponde que el denunciado señale que desconocía los aspectos legales referentes al Derecho de Autor" (Indecopi, Resolución Núm. 0355-2007/ ODA-INDECOPI: 2-12).

\section{Plagio ¿robo de ideas?}

Desde una perspectiva conceptual, para el Diccionario de la Lengua Española idea es "Imagen o representación que del objeto percibido queda en la mente. Plan y disposición que se ordena en la fantasía para la formación de una obra" (RAE, 2001: 843). En la doctrina y la legislación sobre derecho de autor las ideas no son objeto de plagio, por lo que resulta erróneo afirmar que el plagio es el robo de las ideas ajenas. Así lo precisan las normas nacionales e internacionales siguientes:

- Decreto Legislativo Núm. 822 Art. 9². No son objeto de protección por el derecho de autor: Las ideas contenidas en las obras literarias o artísticas, los procedimientos, métodos de operación o conceptos matemáticos en sí [...].

- Decisión Núm. 351 de la Comunidad Andina de Naciones. Art. 7. Queda protegida exclusivamente la forma mediante la cual las ideas del autor son descritas, explicadas, ilustradas o incorporadas a las obras. No son objeto de protección las ideas contenidas en las obras literarias y artísticas, o el contenido ideológico o técnico de las obras científicas, ni su aprovechamiento industrial o comercial. 
De lo anterior se deduce claramente que la ley protege los contenidos originales, aquellos que los autores, valiéndose de ideas o conocimientos previos, plasman en sus obras, sean éstas literarias, artísticas o científicas. Por ejemplo, el tema de la crisis económica europea puede estar presente en la mente, en la idea de cientos o miles de potenciales autores, lo que importa es la forma original, novedosa de expresarse. En ese sentido, la condición básica es la protección a la originalidad e individualidad como manifestación de la personalidad del autor, "[...] la manera personal y peculiar en que cada autor construye a un personaje, esto sí es protegible, ya que aquí es donde se vislumbra el toque creativo y artístico de su autor" (Gaffoglio, s. a.: 2).

Así lo establece el tribunal del Indecopi en su Resolución Núm. 28552010/TPI-.p.4:

El Derecho de Autor protege la creación de las obras; estas creaciones deben ser creaciones formales en las que se protege la forma en que las ideas se han expresado. Las ideas no son obras y, por ende, su uso es libre. No se puede adquirir sobre ellas protección o titularidad alguna, aun cuando sean novedosas.

A su vez, Lipszyc sostiene lo siguiente:

Si se otorgaran derechos exclusivos sobre las ideas consideradas en sí mismas, se obstaculizaría su difusión y con ello se impediría el desenvolvimiento de la creatividad intelectual, es decir, se obstaculizaría la creación de una ilimitada cantidad de obras diferentes. Una misma idea, una misma investigación, un mismo tema, son retomados infinidad de veces. En su desarrollo cada autor aporta la impronta de su personalidad, su individualidad. En ocasiones, el resultado es altamente enriquecedor, en otras, trivial, pero lo que permite que cada generación impulse el lento avance de la civilización es la posibilidad de trabajar sobre lo existente, de proseguir el camino sin tener que rehacer todo y comenzar desde un inicio (1993: 62).

\section{Clases de plagio}

El plagio se manifiesta bajo diferentes modalidades, puede ser el plagio total o el parcial; en el primer caso es la copia literal de todo el contenido de la obra por parte del plagiario, sustituyendo la paternidad del autor y haciéndose pasar como el verdadero padre. En el plagio parcial generalmente están presentes el uso de sinónimos, sustituciones o ligeros cambios de palabras, frases, resúmenes y parafraseo, sin consignar la fuente y disimulando el texto original de la obra.

En el Perú, la tipificación más usada en la fundamentación de las resoluciones emitidas por el Tribunal de Indecopi son las planteadas por Lipszyc, quien las clasifica como sigue: 
La doctrina distingue entre el plagio burdo o servil (el menos frecuente) en que la apropiación de la obra ajena es total o cuasi total, y el plagio "inteligente" en el cual el plagiario trata de disimular el plagio y se apodera de algunos elementos substanciales y originales. Esta última es la forma en que habitualmente se presenta el plagio, razón por la cual se considera que este se debe presentar por las semejanzas y no por las diferencias que presentan las obras implicadas (1993:567).

No obstante, diversos autores ofrecen sus propios criterios de clasificación, así tenemos que Balbuena clasifica el plagio en imitación servil e imitación elaborada.

Esta usurpación de paternidad de la que hablamos puede producirse de diversas maneras. Puede ser que el plagiario pura y simplemente suprima el nombre del autor verdadero sin tocar en lo absoluto el contenido de la obra o que extraiga partes importantes de la ella para incorporarlas a la obra plagiaria. El primero de los casos se denomina imitación servil y el segundo, imitación elaborada. En ambos casos se encontrará tipificada la infracción aunque, en el último de los casos el descubrimiento del delito puede resultar una tarea ardua (s. a.: 9).

Morató cita a Tripathi y Kumar, quienes "[...] han elaborado una de las clasificaciones del plagio más completas, pues enumeran diecisiete tipos de plagio [...]”:

1. Sin cita de fuentes

1.1 Entregar un trabajo ajeno como si fuera propio.

1.2 Se reproducen fragmentos completos sin alteración.

1.3 Se combinan distintas fuentes sin referenciar ninguna.

1.4 Se reproduce el fragmento, del que se cambian ciertas palabras.

1.5 Reformulación de distintas fuentes que conforman el trabajo final.

1.6 "Préstamo" del trabajo propio anterior, con el que viola requisitos de originalidad.

2. Con fuentes citadas (pero aún así plagiadas)

2.1 Se cita al autor, pero sin los datos necesarios para localizar la fuente. La práctica suele esconder otras formas de plagio.

2.2 No se puede localizar las fuentes citadas debido a su referencia incorrecta.

2.3 Se cita al autor, pero no se entrecomilla las palabras textuales, por lo que se hace pasar por propia una interpretación ajena.

2.4 Las citas y referencias son correctas, pero prácticamente constituyen la mayor parte del artículo.

2.5 En algunos fragmentos se citan de manera correcta las fuentes pero en otros se introduce una paráfrasis de esas mismas fuentes, esta vez sin reconocimiento expreso. 
3. Otros tipos de plagio

3.1 Se reproducen citas directas sin comillas.

3.2 Cambios de algunas palabras de la cita, que se reproduce sin comillas.

3.3 Emplear el lenguaje creativo de un autor sin hacer constar el debido reconocimiento.

3.4 Hacer pasar una idea ajena como propia.

3.5 Seguir el razonamiento de otro autor en un orden aproximado al que se desarrolla en el artículo original.

3.6 Plagio de datos procedentes de otros estudios (Morató, 2012:363).

\section{Causas del plagio}

Para ser completamente claros: el plagio se considera como el hurto del trabajo intelectual de otra persona. Entre las múltiples causas por las cuales los estudiantes cometen este error, puede identificarse el creer que las ideas "son de todo el mundo" así como una inadecuada y pobre metodología para saber citar (Cerezo, 2006: 32).

En el ámbito académico se plantea y discute la presencia cada vez más recurrente del plagio, conducta que afecta sensiblemente el proceso de enseñanza-aprendizaje y la investigación. Esto se constituye, además, en una real amenaza al progreso de la ciencia, el arte y la tecnología, al desincentivar a los autores e inventores con la apropiación ilegal de sus obras.

$\mathrm{Al}$ respecto, Pastor afirma:

[...] los alumnos adoptan y presentan en sus trabajos de investigación como ideas propias, teoría e hipótesis realizados por otros investigadores, y son estas tecnologías asociadas a la Sociedad de la Información, las que facilitan esta práctica éticamente reprobable y académicamente incorrecta. El plagio se ha convertido en una constante de nuestra sociedad. Pues no sólo ha logrado invadir el mundo académico, sino que también ha incursionado en otros espacios tales como la música, la pintura, el cine, etc., es decir, las ciencias y artes en general (2009: 106).

Diversas investigaciones sostienen que una de las primeras causas del plagio es la presencia de las nuevas tecnologías de la información, en particular la aparición de Internet, la cual gracias a su capacidad de almacenar cantidades inimaginables de datos e información (ahora se habla de "zettabytes") ha dado lugar a comportamientos ilícitos, entre ellos el llamado "ciber plagio académico", frente al cual observamos un alto grado de permisividad, no sólo de la sociedad, sino particularmente de las instituciones educativas, ya que pocas cuentan con reglamentos y medidas concretas que pongan freno al fraude o la deshonestidad académica. 
Esto sucede de tal modo que Comas, Sureda, Casero y Morey, luego de los resultados de una larga investigación, se preguntan indignados:

¿Por qué si los datos son tan sangrantes como los que demuestra este trabajo y otros similares, no se implementan medidas en nuestro país para mejorar la situación? ¿Es posible que todo lo relatado en estas páginas no se intente remediar por intentar mantener una especie de pacto de silencio entre alumnado y profesorado que ayude al mantenimiento de cierto statu quo en la institución universitaria? (2011:223).

Como tal, lo que ocurre en el ámbito educativo no es más que el reflejo de la sociedad en su conjunto, que atraviesa por una aguda crisis de valores, de cumplimiento de normas y responsabilidades, reflejada en la crisis de sus instituciones, que entre otras manifestaciones incluye la falta de ética que conlleva al escaso respeto de lo ajeno. A ello se suma que desde el campo de lo jurídico, la jurisdicción de los países se diluye por falta de una regulación mundial en la red, que hace suponer que la información que ella alberga es de todos y a la vez de nadie. Así lo advertía Vargas Llosa cuando recientemente fue suplantado por otro: "[...] el tema de los derechos de autor, del Copyright, en el mundo digital es todavía un bosque confuso, objeto de múltiples negociaciones en los que todavía nadie se pone de acuerdo [...]" (2012: 11). "Las fronteras no existen en internet y los Estados tienen serias dificultades para delimitar sus jurisdicciones. Es indudable que el Estado intenta regular unilateralmente, sin contar con la anuencia de las demás entidades, cualquier asunto que sucede en su territorio" (Téllez, 2009:103).

En un reciente estudio, Sureda, Comas y Morey (2009) agrupan en dos los factores que concurren en la incidencia del plagio académico: los que se encuentran en el propio sistema educativo (intrasistema) y aquellos otros que le son externos. Señalan además que el plagio se debe a determinadas características y comportamientos del profesorado, a determinadas características y comportamientos del alumnado, a determinadas características de la universidad, básicamente la masificación; al desarrollo de las TIC y a determinados valores sociales predominantes.

Cabedo cita a Parki sobre otros factores más que condicionan el plagio:

1. Género. Es más común el plagio entre hombres que entre mujeres.

2. Edad y madurez. Los jóvenes suelen plagiar más que los mayores.

3. Cociente intelectual. La gente con cociente intelectual menor suele copiar más, aunque también se da el proceso inverso: alumnos con un nivel elevado de cociente intelectual copian también en gran medida.

4. Vida social. Alumnos con una vida social activa suelen copiar más porque el 
tiempo que dedican a la parcela social les impide dedicarse más intensamente a la preparación de trabajos y exámenes.

5. Factores de la personalidad del estudiante. Los estudiantes copian si tienen un comportamiento agresivo, pero también si quieren homogeneizarse con sus iguales.

6. Actitud del estudiante hacia la asignatura. En este caso, la motivación del alumnado influye en una mayor o menor copia académica.

7. Todos estos factores están presentes en la conducta y en el entorno del plagiario, por esto cabe afirmar que, al ser un hecho complejo, éste debe ser ampliamente analizado (Cabedo, 2010: 10).

Por lo señalado hasta aquí consideramos que uno de los factores en los que se debe incidir para frenar el plagio es el aspecto educativo, por ser éste uno de los más importantes en el desarrollo de las capacidades del ser humano, cuyas consecuencias se extienden a lo largo de toda su vida.

Soto enfatiza:

Como se vio con antelación existen muchos tipos de plagio que se pueden cometer, la mayoría de los cuales se podrían prevenir con una apropiada educación sobre cómo evitar el plagio, tanto en universidades como en escuelas y colegios. De esta forma los alumnos se van acostumbrando desde temprano a citar correctamente y a no dejar para el final la bibliografía en sus trabajos, de manera que al menos así no cometan un plagio accidental o sin intención (2012: 12).

En efecto, se debe trabajar con responsabilidades compartidas, tanto por los padres de familia como por los maestros, las instituciones educativas en general y el Estado. Así lo establecen diversos planes e instrumentos normativos aprobados por el Estado, como es el Plan de Acción de Educación para Todos (2005-2015) que a la letra señala:

Los principios sobre los cuales se funda el Plan de Acción del EPT parten de entender a la educación como un derecho universal, inherente al ser humano [...]. La educación también debe promover la conciencia moral de las personas, una ética que se ejerza en el espacio público, y que forme una sociedad sustentada en la verdad, la justicia, la libertad, el amor, la solidaridad, la paz, la responsabilidad y el respeto (Vexler, 2005: 16).

Es preciso realizar una intensa labor desde la familia, inculcando valores y la conciencia moral en los niños. Por su parte el maestro debe desarrollar en el educando el dominio de destrezas y capacidades básicas en la lectoescritura, de tal forma que aprenda a leer y comprender para luego 
poder resumir, comentar, analizar y sintetizar textos con autonomía y esfuerzo personal, usando sus propios términos a fin de lograr progresivamente una fluida comunicación oral y escrita, contribuyendo así al desarrollo de sus capacidades mentales de orden superior.

Gutiérrez y Montes de Oca citan a Arenzana, quien señala que:

[...] el acto de leer se convierte en una capacidad compleja, superior y exclusiva del ser humano en la que se comprometen todas sus facultades simultáneamente y que comporta una serie de procesos biológicos, psicológicos, afectivos y sociales que lo llevan a establecer una relación de significado particular con lo leído y de este modo, esta interacción lo lleva a una nueva adquisición cognoscitiva (Gutiérrez y Montes de Oca, 2004: 1).

Desde que un niño aprende a leer, debe interiorizar que las imágenes que percibe o el texto que lee son producto de la creación ajena, del esfuerzo mental de su autor y que eso merece respeto, porque los textos y demás obras que seguirá conociendo más allá de su vida estudiantil constituirán elementos indispensables de superación personal. Y también para efectos de complementar su aprendizaje el alumno debe saber que sí puede copiar el contenido de textos ajenos, indistintamente de los soportes en los que se encuentre, para lo cual necesita aprender a usar las citas y darle crédito al autor, e identificar que aquello que copia literalmente no le pertenece; como tal, debe anotar con claridad a quien corresponde la frase, el párrafo, el texto, el gráfico o la imagen que reproduce. Recordemos al respecto lo que menciona la UAEM: "[...] el plagio siempre es grave porque va precisamente contra una de las normas que dan la esencia a la educación: la búsqueda de la verdad y la justicia, porque roba ideas, imágenes, proyectos a otro. [...]” (2002: 1).

No obstante que el alumno accede al nivel educativo superior con sus propios valores y patrones de conducta, es responsabilidad de las instituciones implementar mecanismos de prevención de conductas deshonestas e ilícitas; como primer paso debería sensibilizar permanentemente a los miembros de la comunidad con campañas a favor de la honestidad académica, tal como lo hace la PUCP con la frase reiterativa en los diferentes ambientes de la universidad "no te comas las comillas", de tal forma que se logre internalizar el respeto a la creación ajena, y para que se entienda y valore que la condición básica del progreso de la humanidad ha sido siempre la creatividad y el ingenio de autores e inventores. A la par, valdría la pena establecer la obligatoriedad de los docentes para controlar y hacer un seguimiento permanente de los alumnos, a fin de revertir la pereza mental, el facilismo y la ley del menor esfuerzo que les impiden pensar y crear por sí mismos. 


\section{Consecuencias del plagio}

Desde el momento que el plagio es la apropiación de la creación ajena, tipificada como una falta o un delito, puede traer consigo una serie de consecuencias de orden personal, social, académico y laboral, entre otras.

a) Consecuencias de carácter personal. El ser humano se mueve en el marco de normas y valores que condicionan su comportamiento. Actuar en contra de la moral al apropiarse de lo ajeno lo convierte en un inmoral carente de valores.

Nos empobrece como personas, es un acto egoísta que cercena la creatividad e innovación del ser humano (que debe ser responsable de la veracidad y calidad de su trabajo), y además puede entrañar responsabilidades penales o sanciones académicas, pero sobre todo supone vulnerar los derechos morales relacionados con la autoría, una de las partes más importantes de los derechos de autor (Domínguez, 2012: 498).

Por otra parte, este tipo de conductas limitan el aprendizaje permanente y el desarrollo de las capacidades y potencialidades mentales de orden superior, como la investigación, la descripción, el uso de la información, el análisis y la síntesis, que le permiten al individuo conocer e interpretar el mundo, la sociedad en la que vive y la "morada" en la que habita, que al decir de Polo: "Tres moradas constituyen nuestro ser: la morada natural, social e interior" (2001:35).

b) Consecuencias de carácter académico. De haber una reglamentación en los centros de educación, tanto básica como superior, el plagiario será pasible de sanción por parte de la institución que compruebe tal conducta.

c) Consecuencias de carácter administrativo y penal. En el ámbito administrativo la entidad que protege la propiedad intelectual es Indecopi, que a nombre del Estado peruano sanciona el plagio a través de un proceso contencioso administrativo. Si el caso lo amerita, puede dar cuenta al Ministerio Público para que investigue el hecho y formalice la denuncia penal respectiva. En el ámbito judicial, el plagio es una figura delictiva sancionada en el Código Penal. De concurrir los presupuestos que la ley exige, el plagiario puede ser juzgado y condenado en el Poder Judicial hasta con ocho años de cárcel.

d) Consecuencias de carácter laboral. Si en el marco de una relación de trabajo se comprueba la conducta deshonesta del plagiario, puede ser objeto de un proceso interno sancionatorio y hasta ser separado del centro laboral, sea éste una institución pública o privada. 
e) Consecuencias de carácter social. Otra de las consecuencias deplorables es que la sociedad se ve engañada con una obra producto del robo de la creación ajena. Aquí se atenta contra la confianza, la buena fe que se tiene sobre los bienes y servicios que se adquieren.

Cavanillas sostiene:

[...] plagiar supone «robar al autor y engañar al destinatario de la obra plagiada». Un mismo acto de plagio afecta a dos grupos de intereses: a) los intereses del autor (y, en su caso, el del titular de los derechos de explotación de la obra, como es, por ejemplo, el editor); b) los intereses del destinatario de la obra, a quien se pretende engañar haciéndola pasar como propia (2008: 2).

f) Frena el desarrollo de la ciencia, la técnica y el arte. Gracias a la capacidad creativa de autores e inventores a lo largo de la historia, la humanidad ha logrado el avance y desarrollo que ahora la sociedad disfruta. Así como la rueda, la energía, el vapor y la revolución de las nuevas tecnologías de la información han sido producto de mentes lúcidas, estos influyen positivamente en el desarrollo de la sociedad. Sin embargo, conductas como el plagio desincentivan al autor e inventor y consecuentemente frenan el desarrollo científico y tecnológico del país.

\section{Detección del plagio}

Tal como señalábamos líneas arriba, el plagio se ha convertido en una conducta generalizada, en particular en los distintos niveles del sistema educativo; diferentes estudios dan cuenta de que un gran porcentaje de alumnos declaran haber cometido plagio alguna vez en su vida estudiantil. Es más, tienen la percepción de que la mayoría de estudiantes cometen plagio superior; en especial de las fuentes de Internet o de diversas páginas web, donde dada la enorme cantidad de información que albergan es difícil detectar el plagio. Lo preocupante es que en la sociedad tal conducta es considerada sólo una falta leve, muestra de lo cual es que no existe reglamentación en la mayoría de las instituciones educativas como es el caso del Perú, donde casi no se conocen casos que hayan sido objeto de sanción en alguna instancia por una autoridad competente.

Morató cita algunos trabajos de investigación que muestran este grave problema:

Más de tres cuartas partes de la población estudiantil han plagiado parcial o totalmente un trabajo con información extraída de Internet al menos una vez en su paso por la universidad (Bowman, 2004). Aunque otros estudios señalan una 
proporción menor, la práctica está tan extendida que Comas, Urbina y Sureda (2005) hablan de una "generación "copiar y pegar". Hansen (2003: 773) sitúa el porcentaje de estudiantes que han plagiado entre el 40 y el 50 por ciento, y afirma que existen dos causas fundamentales que llevan a los estudiantes a recurrir al plagio. La primera es el convencimiento de que no serán descubiertos; la segunda obedece a la mala influencia que ejerce el contexto social: "en el clima ético actual consideran el plagio como algo trivial si se compara con casos más que conocidos de deshonestidad política o empresarial” (2012:361).

No obstante, detectar y probar el plagio es una labor compleja; no sólo hacen falta conocimientos, experiencia y minuciosidad, sino el apoyo de herramientas que ayuden en su detección. Para probar el plagio es menester que la conducta del plagiario sea real, evidente y puesta al descubierto, hecho que obliga a buscar los mecanismos más adecuados para su comprobación. Ante la sospecha de plagio, la primera condición es que paralelo a la obra producto del plagio se demuestre la preexistencia documental de la obra original del autor plagiado, una vez ubicada ésta se debe poner en marcha un minucioso mecanismo de comparación del contenido (el método de "los pasajes paralelos"), sea en forma total o parcial, preferentemente por peritos expertos en la materia. Además, las normas administrativas y penales admiten como medios probatorios la confesión de las partes, el informe de peritos, los documentos públicos o privados que se actúan en el proceso y la declaración de testigos, quienes podrán aportar con su dicho las circunstancias que esclarezcan el hecho.

En la actualidad existen novedosas herramientas tecnológicas, tanto comerciales como de uso libre, que facilitan la detección del plagio. Así, tenemos los motores de búsqueda más importantes y al alcance de todos como Google, Yahoo, Javi, Altavista y el programa Turtunin, que facilitan el rastreo en la red a fin de ubicar los documentos originales o similares para su efectiva comparación.

A continuación, detallamos algunas de estas herramientas que se encuentran en la red.

- Google y Google Scholar. Son los motores de búsqueda más comunes y más sencillos de usar, con sólo ingresar entre comillas la frase o el párrafo que se necesita detectar, en tiempo real responderán a la búsqueda. El amplio acervo de Google Books y Google Scholar incluye libros en texto completo y artículos de revista, entre otros documentos.

- The Plagiarism Checker. Permite a través de Google buscar textos mucho más grandes y completos.

- Articlechecker. Muy similar a la herramienta anterior, funciona a través de los buscadores Yahoo y Google. 
- Plagium. Realiza la búsqueda en Google, la ventaja es que permite ubicar los documentos originales en varios idiomas.

- PlagiarismDetect. Herramienta gratuita que facilita trabajar con documentos completos.

- Duplichecker. Permite ingresar mayor cantidad de datos y muestra el enlace del documento original, lo que hace más fácil acceder al contenido.

- The Plagiarism Checker: Similar a la herramienta anterior, con base en los términos "Possible plagiarism" conduce al enlace del documento original.

- SeeSources. Trabaja con documentos enteros o pequeños extractos, facilitando la búsqueda en la red de documentos similares al de la consulta.

- WCopyFind. Este es un escáner que ayuda manualmente a comparar el plagio entre dos documentos, sin que haya necesidad de acudir a la red. Se debe tener a la vista el documento de comparación.

- Viper. Software gratuito que se usa para detectar el plagio.

Además es importante anotar que actualmente ya se plantean novedosas técnicas, como la de Cabedo (2010), que desde la lingüística forense propone una metodología para el análisis de textos con miras a la detección del plagio.

Tabla 1. Aspectos en la detección del plagio.

\begin{tabular}{|c|c|}
\hline \multicolumn{2}{|c|}{ Cantidad de páginas, párrafos, líneas, palabras y caracteres con y sin espacio } \\
\hline Información tipográfica & Subrayados, negrita, cursiva, mayúsculas, versales... \\
\hline Elementos paratextuales & Títulos, subtítulos, apéndices, anexos... \\
\hline Tipología textual & $\begin{array}{l}\text { Descriptivo, argumentativo, prescriptivo... } \\
\text { Registro (formal/informal). }\end{array}$ \\
\hline Disposición estructural & $\begin{array}{l}\text { Ausencia o presencia de marcas de división estructural. Por ejemplo: I. Intro- } \\
\text { ducción II. Estado de la cuestión... } \\
\text { Orden de la información introducida. }\end{array}$ \\
\hline Contenido del texto & $\begin{array}{l}\text { Tema. } \\
\text { Argumento. } \\
\text { Perspectiva narrativa. Por ejemplo: un texto argumentativo puede defender } \\
\text { o atacar una postura. }\end{array}$ \\
\hline Plano morfosintáctico & $\begin{array}{l}\text { Categorías gramaticales: cantidad de sustantivos, verbos, adjetivos y cate- } \\
\text { goría predominante. } \\
\text { Modo indicativo/subjuntivo de los verbos. } \\
\text { Orden de palabras. } \\
\text { Construcciones anómalas y errores ( }{ }^{*} \text { me se, }{ }^{\star} \text { la digo...). }\end{array}$ \\
\hline Plano léxico semántico & $\begin{array}{l}\text { Semántica de las palabras: sustantivos concretos/abstractos, adjetivos, et- } \\
\text { cétera. }\end{array}$ \\
\hline Plano pragmático & $\begin{array}{l}\text { Componente directo/indirecto del nivel oracional: ironías, humor. } \\
\text { Introducción de elementos coloquiales: marcadores del discurso (bueno, va- } \\
\text { mos, venga...), realzadores del emisor: yo, uso de la conjunción que para } \\
\text { todo valor subordinado (incluido el adverbial), etcétera. }\end{array}$ \\
\hline
\end{tabular}

Fuente: Cabedo, 2010: 12. 
Como se puede observar, la tabla muestra un conjunto de aspectos que han sido desagregados en subaspectos, que van desde la tipografía, el tipo de texto, el contenido, la morfosintaxis y otros, a fin de ser aplicados con minuciosidad en la comparación de documentos sospechosos de plagio.

En el ámbito de la Ingeniería Informática, Alva desarrolla en su tesis un método y una técnica original de detección del plagio de documentos digitales.

Uno de los métodos que se emplea es el Document Fingerprinting, el cual es un algoritmo que permite extraer un conjunto de valores numéricos del documento que representan a varias porciones del mismo. El conjunto de estos valores recibe el nombre de fingerprint del documento. Mediante la comparación de las fingerprintgs de distintos documentos es que se puede detectar si es que los documentos poseen secciones comunes y, por tanto, se ha incurrido en plagio. En este proyecto, se implementa un sistema de información que emplea una instancia específica del algoritmo Document Fingerprinting, llamada Winnowing, para obtener un mejor resultado en la comparación. Asimismo, se provee al sistema de una interfaz de usuario apropiada para el análisis de documentos en búsqueda de plagio (2009: 2).

En la tabla siguiente el autor compara una serie de atributos de las herramientas específicas y alternativas de detección del plagio.

Tabla 2. Comparación de atributos de herramientas para la detección del plagio.

\begin{tabular}{|c|c|c|c|c|c|c|c|c|}
\hline \multirow[t]{3}{*}{ Atributos } & \multicolumn{8}{|c|}{ Herramientas para detección } \\
\hline & \multicolumn{7}{|c|}{ Herramientas específicas } & \multirow{2}{*}{$\begin{array}{c}\text { Herramientas } \\
\text { alternativas } \\
\text { Google } \\
\text { Yahoo } \\
\text { Altavista }\end{array}$} \\
\hline & Turnitin & Eve2 & $\begin{array}{l}\text { Copy } \\
\text { Catch } \\
\text { Gold }\end{array}$ & $\begin{array}{l}\text { Word } \\
\text { Check }\end{array}$ & Glatt & Moss & Jplag & \\
\hline \multicolumn{9}{|l|}{$\begin{array}{l}\text { Tipo de herramienta de texto } \\
\text { sobre la que opera }\end{array}$} \\
\hline ¿Verifica código fuente? & - & - & - & - & - & $x$ & $x$ & - \\
\hline ¿Verifica texto libre? & $\mathrm{x}$ & $x$ & $x$ & $x$ & $\mathrm{x}$ & - & - & $\mathrm{x}$ \\
\hline \multicolumn{9}{|l|}{$\begin{array}{l}\text { Tipo de herramienta de } \\
\text { corpus sobre la que opera }\end{array}$} \\
\hline ¿Opera intra-corporalmente? & $\mathrm{x}$ & - & $\mathrm{x}$ & $\mathrm{x}$ & - & $x$ & $\mathrm{x}$ & - \\
\hline ¿Opera extra-corporalmente? & $x$ & $x$ & - & - & - & - & - & $x$ \\
\hline \multicolumn{9}{|l|}{ Otros atributos } \\
\hline $\begin{array}{l}\text { ¿Diseñado para uso de } \\
\text { estudiantes? }\end{array}$ & $x$ & - & - & - & - & - & - & $x$ \\
\hline $\begin{array}{l}\text { ¿Diseñado para uso de } \\
\text { profesores? }\end{array}$ & $\mathrm{x}$ & $\mathrm{x}$ & $\mathrm{x}$ & $\mathrm{x}$ & $x$ & $\mathrm{x}$ & $\mathrm{x}$ & $\mathrm{x}$ \\
\hline ¿Respuesta automática? & - & $x$ & - & $x$ & - & - & - & $x$ \\
\hline ¿Libre? & - & - & - & - & - & $x$ & $\mathrm{x}$ & $x$ \\
\hline
\end{tabular}

Fuente: Alva, 2009: 29 


\section{El plagio: infracción al derecho de autor}

El derecho de autor es parte de la propiedad intelectual que trata de las creaciones de la mente, sean obras literarias, artísticas o científicas. "Por 'propiedad intelectual' se entiende, en términos generales, toda creación del intelecto humano. Los derechos de propiedad intelectual protegen los intereses de los creadores al ofrecerles prerrogativas en relación con sus creaciones" (OMPI, s. a.: 3). $\mathrm{El}$ derecho de autor es una rama del derecho privado que protege y regula la creación del autor, que es una persona natural con derechos morales y patrimoniales sobre su obra. Para Guinchat y Menou: "El derecho de autor es un instrumento jurídico que garantiza la protección material y moral del autor de una obra, o de sus causahabientes, por un período determinado" (1992: 361). Diversos tratados y normas internacionales suscritos por el Perú garantizan la protección de los derechos morales y patrimoniales del autor, reconocen que el autor tiene derecho a la propiedad de su creación, que por ser parte de sus derechos fundamentales deben ser reconocidos sin la exigencia de ninguna formalidad.

$\mathrm{Al}$ respecto, Antequera y Ferreyros acotan:

Una tendencia de casi unánime aceptación universal otorga la protección a las obras del ingenio por el solo hecho de su creación, sin necesidad del cumplimiento de ningún requisito formal, de manera que el registro de la obra tiene únicamente carácter declarativo y constitutivo de derechos (1996: 72).

A continuación las bases jurídicas más importantes en al ámbito internacional:

a) Declaración Universal de los Derechos Humanos. Artículo 27. Toda persona tiene derecho a la protección de los intereses morales y materiales que le correspondan por razón de las producciones científicas, literarias o artísticas de que sea autora.

b) Convenio de Berna. Artículo 6 bis. Párrafo 1. Independientemente de los derechos patrimoniales del autor, e incluso después de la cesión de estos derechos, el autor conservará el derecho de reivindicar la paternidad de la obra y de oponerse a cualquier deformación, mutilación u otra modificación de la misma o a cualquier atentado a la misma que cause perjuicio a su honor o a su reputación.

c) Decisión 351 de la Comunidad Andina de Naciones. Artículo 11. El autor tiene el derecho inalienable, inembargable, imprescriptible e irrenunciable de: a) Conservar la obra inédita o divulgarla; b) Reivindicar la paternidad de la obra en cualquier momento; y, c) Oponerse a 
toda deformación, mutilación o modificación que atente contra el decoro de la obra o la reputación del autor. A la muerte del autor, el ejercicio de los derechos morales corresponderá a sus derechohabientes, por el plazo a que se refiere el Capítulo VI de la presente Decisión. Una vez extinguido el derecho patrimonial, el Estado u otras instituciones designadas asumirán la defensa de la paternidad del autor y de la integridad de su obra.

En el Perú, la base legal se encuentra en las normas siguientes:

a) Constitución Política del Perú de 1993. Artículo $2^{\circ}$. Toda persona tiene derecho a: [...] 8. A la libertad de creación intelectual, artística, técnica y científica, así como a la propiedad sobre dichas creaciones y a su producto. El Estado propicia el acceso a la cultura y fomenta su desarrollo y difusión.

b) Código Penal (2007). Artículo 219. Será reprimido con pena privativa de libertad no menor de cuatro ni mayor de ocho años y noventa a ciento ochenta días multa, el que con respecto a una obra, la difunda como propia, en todo o en parte, copiándola o reproduciéndola textualmente, o tratando de disimular la copia mediante ciertas alteraciones, atribuyéndose o atribuyendo a otro, la autoría o titularidad ajena.

c) Código Civil (2008). Artículo 18. Protección de los derechos de autor e inventor. Los derechos del autor o del inventor, cualquiera sea la forma o modo de expresión de su obra, gozan de protección jurídica de conformidad con la ley de la materia.

d) Decreto Legislativo Núm. 822 Ley sobre el Derecho de Autor.

Como tal, el bien jurídico tutelado es el derecho exclusivo que tiene el autor a la protección legal de sus derechos morales y patrimoniales.

\section{Protección a los derechos morales}

Los derechos morales son un conjunto de facultades que la ley le otorga al autor por ser el padre de la obra; consecuentemente, protege su nombre y está facultado a exigir el respeto a sus derechos sobre el fruto de su creación. "Son derechos morales: a) El derecho de divulgación. b) El derecho de paternidad. c) El derecho de integridad. d) El derecho de modificación o variación. e) El derecho de retiro de la obra del comercio. f) El derecho de acceso" (Dec. Leg. Núm. 822 Art. 22). Los mismos que son perpetuos, inalienables, inembargables, irrenunciables e imprescriptibles. A la muerte 
del autor, los derechos morales serán ejercidos por sus herederos, mientras la obra esté en dominio privado, salvo disposición legal en contrario (Art. 21).

Teniendo en cuenta tales características, el autor puede disponer de su obra, publicarla, ejecutarla, representarla, enajenarla, traducirla o adaptarla impidiendo a terceros toda acción que carezca de su autorización. La estrecha relación entre el plagio y el derecho de autor es que uno de los rasgos principales de la conducta del plagiario es precisamente atentar contra los derechos morales del autor, generalmente sustituyendo el nombre del autor original por el suyo, infringiendo así el derecho de paternidad e impidiendo que se le reconozca la condición de padre de la obra sin otorgarle los créditos que merece.

Al respecto, en el Perú el Tribunal de Indecopi sostiene, en su Resolución Núm. 2855-2010/TPI- p. 5:

Las facultades de orden moral están dirigidas a proteger la esfera personal del autor en relación con su creación; es decir, "protegen la personalidad del autor en relación con su obra” (Lipszyc, 1993: 62). Se caracterizan por ser absolutos, ya que son oponibles a todos -inclusive al propietario del soporte de la obra-; son perpetuos, ya que la paternidad del autor y el respeto a la integridad de la obra no pasan al dominio público; son inalienables, pues no pueden ser cedidos o transferidos por ningún acto o contrato; son inembargables e inexpropiables. Ya que no tienen contenido patrimonial; son irrenunciables, por su carácter inalienable, individual y personalísimo y son imprescriptibles porque no se adquieren ni se pierden por acción del tiempo (Lipszyc, 1993: 154). Estos derechos están contenidos en los artículos 11 de la Decisión 351 de la Comunidad Andina de Naciones y 22 del Decreto Legislativo Núm. 822.

\section{Protección al derecho patrimonial}

El derecho patrimonial es la facultad que tiene el autor de obtener beneficios económicos gracias al fruto de su creación. "El derecho patrimonial protege el valor económico de la obra producto del ingenio, y como tal, el autor puede explotarlo económicamente y obtener un ingreso con su comercialización. A la muerte de éste, los derechos patrimoniales corresponden a sus derechohabientes" (Quiroz, 2003: 59). Para obtener estos beneficios el titular puede autorizar la explotación de su obra por cualquier medio conocido o por conocerse, la propia norma así lo señala. De manera que terceros pueden explotarla económicamente sin infringir la ley, actuando en ejercicio de una potestad llamada cesión de derechos, lo que significa que el nuevo titular de los derechos patrimoniales sobre la obra será el cesionario. El Dec. Leg. Núm. 822 estipula al respecto: 
Artículo $31^{\circ}$. El derecho patrimonial comprende, especialmente, el derecho exclusivo de realizar, autorizar o prohibir:

a) La reproducción de la obra por cualquier forma o procedimiento.

b) La comunicación al público de la obra por cualquier medio.

c) La distribución al público de la obra.

d) La traducción, adaptación, arreglo u otra transformación de la obra.

e) La importación al territorio nacional de copias de la obra hechas sin autorización del titular del derecho por cualquier medio incluyendo mediante transmisión.

f) Cualquier otra forma de utilización de la obra que no está contemplada en la ley como excepción al derecho patrimonial, siendo la lista que antecede meramente enunciativa y no taxativa.

No obstante, la ley establece un conjunto de excepciones llamadas "límites al derecho de comunicación y reproducción" que le permiten a la sociedad acceder a las obras ajenas, siempre que se cite la fuente, resolviendo así la dicotomía de protección al derecho de autor y el derecho a la cultura y el acceso a la información, que son derechos fundamentales de la persona humana.

Castillo refiere:

A esta posición antagónica entre el derecho de autor a recibir contraprestación por su obra y el derecho de acceso a la cultura ya se ha referido el doctor Antequera Parilli. Quien expresa que ante esta posición se ha pretendido que el interés individual material del autor debe sacrificarse ante el interés colectivo del disfrute de bienes culturales (2012: 127).

\section{Sanción al plagio en el Perú}

Desde el campo jurídico, el término "plagio" no ha sido incorporado explícitamente en la ley peruana; sin embargo, lo encontramos en una serie de estudios de carácter doctrinal, en el contenido de diversas jurisprudencias dadas por Indecopi y en diferentes investigaciones realizadas en el ámbito académico. Es así que la doctrina considera al plagio un delito, tipificado como una conducta ilícita siempre y cuando concurran una serie de condiciones. Lipszyc las enumera:

a) Que se trate de una obra protegida [...];

b) Que la utilización no se haya efectuado al amparo de una limitación del derecho [...];

c) Que el plazo de protección se encuentre vigente [...];

d) Que la conducta del agente se adecue a una figura típicamente incriminada [...];

e) La existencia de dolo en el agente [...] (citada en Balbuena, s. a.: 8). 
Agrega la autora:

En lo que al delito de plagio se refiere, la doctrina sostiene que la perfección del tipo requiere de la concurrencia de las siguientes condiciones:

1. Usurpación de la paternidad;

2. La ausencia de consentimiento del autor;

3. La divulgación; y

4. El elemento intencional o dolo (citada en Balbuena, s. a.: 9).

En el Perú, la vulneración a los derechos morales del autor se sanciona en la vía administrativa (Indecopi) y en la vía penal (Poder Judicial). En la vía administrativa, el procedimiento se lleva a cabo en dos instancias; en la primera, es competencia de la Dirección de Derecho de Autor admitir la denuncia y resolverla, y en la segunda y última instancia, en vía de apelación, corresponde a la Sala de Propiedad Intelectual confirmar la resolución en todo o en parte o revocarla, con lo cual se agota el proceso. En la vía judicial se juzga al plagiario de acuerdo con el Código Penal, que tipifica la conducta ilícita como "Falsa atribución de autoría de obra", la cual de oficio o a demanda de parte inicia la acción penal ante el Ministerio Público al ser puesto en conocimiento del hecho.

El Artículo $219^{\circ}$ del Código Penal (2007) indica:

Falsa atribución de autoría de obra. Será reprimido con pena privativa de libertad no menor de dos ni mayor de ocho años y sesenta a ciento ochenta días-multa, el que con respecto a una obra, la difunda como propia, en todo o en parte, copiándola o reproduciéndola textualmente, o tratando de disimular la copia mediante ciertas alteraciones, atribuyéndose o atribuyendo a otro, la autoría o titularidad ajena.

No obstante, en el ámbito académico, en particular en las universidades que forman parte del Sistema Universitario Peruano, ni la Ley Universitaria (Núm. 23733) ni los estatutos contemplan este tipo de infracciones, que las más de las veces son ignoradas; cuando se presenta un plagio las universidades se vuelven renuentes a sancionarlo, salvo algunas que aisladamente han incorporado en sus reglamentos internos acciones y sanciones con el fin de prevenir y reprimir estas conductas. Así tenemos a la Pontificia Universidad Católica del Perú (PUCP) cuyo Reglamento Disciplinario señala:

Art. $4^{\circ}$. Infracciones Graves [...] c) Cometer plagio o cualquier otro acto que intente alterar o distorsionar la objetividad de la evaluación académica [...].

Art. $5^{\circ}$. Sanciones aplicables. [...] Quienes incurran en infracciones de mayor 
gravedad, contempladas en el artículo $4^{\circ}$ del presente reglamento, podrán ser sancionados con suspensión académica hasta por veinticuatro meses o con expulsión de la Universidad.

Hacemos referencia a un caso que en su momento (2009) mereció rechazo en los medios académicos. En aplicación del Reglamento y de acuerdo a las normas internas, la PUCP sancionó a dos alumnos que incurrieron en plagio. Como era de esperar, los sancionados apelaron a la máxima instancia universitaria que es la Asamblea Nacional de Rectores, que a través del Consejo de Asuntos Contenciosos Universitarios (Codacun) anuló la sanción impuesta por la Universidad, procediendo sólo a una simple "amonestación" con argumentos carentes de toda lógica y sentido común. Tal decisión fue duramente criticada por diferentes sectores de la sociedad y por la misma Universidad, que hizo público un comunicado señalando que este tipo de resoluciones crea un precedente nefasto en contra de la ética y los valores y desmoraliza a la comunidad universitaria. Aquí un extracto del comunicado:

“ [...] En marzo del 2009, dos estudiantes fueron sancionados por el Consejo Universitario de la PUCP con suspensión por haber cometido plagio en la elaboración de sendos trabajos de investigación, al utilizar párrafos de obras de autores sin realizar las citas correspondientes; es decir, hicieron pasar como propias las ideas ajenas [...] acto que contraviene la tarea principal de la universidad: pensar y reflexionar. Y no la mera transmisión y repetición del conocimiento”. Esta sanción fue objeto de apelación a la Asamblea Nacional de Rectores por parte de los alumnos sancionados. El Consejo de Asuntos Contenciosos Universitarios (Codacun), que es la máxima instancia nacional en este tipo de casos, anuló la sanción impuesta por la PUCP y sólo procedió a la amonestación, bajo el argumento que "los estudiantes se comportan de manera natural al imitar y copiar en exceso sin indicar las fuentes" y que "la enseñanza consiste fundamentalmente en la repetición constante de ideas y formulaciones ajenas, omitiéndose muchas veces, por economías, las fuentes”. (http://blog.pucp.edu.pe/archive/774/2010-4-19)

En julio de 2012, la Universidad Nacional Mayor de San Marcos aprobó el Reglamento de Proceso Disciplinario para Alumnos de la Universidad Nacional Mayor de San Marcos, el cual señala: "Capítulo III. De las Faltas. Artículo 6. Son faltas susceptibles de sanción disciplinaria las siguientes: El plagio parcial o total de trabajos de investigación". Esto constituye un paso importante en la sanción a conductas deshonestas que a todas luces se incrementan en el ámbito académico y que debe servir de precedente para que otras instituciones de educación superior aprueben este tipo de instrumentos normativos, a fin de preservar la ética y la honestidad académica en los miembros de la comunidad universitaria. 
Y para concluir, es ilustrativa la cita de Morató, quien reproduce el texto siguiente texto tomado de la página web de la Universidad de Navarra:

Sería un error describir el plagio sólo como una falta menor, o como un asunto de formalidad académica. Por el contrario, el plagio es una falta grave de la honradez académica. Es un principio de honestidad intelectual que todos los miembros de la comunidad científica reconozcan su deuda con los autores de las ideas, trabajos y datos que forman la base del trabajo que presentan. Hacer pasar por propio el trabajo de otros es no sólo muestra de falta de compañerismo, sino que también significa un fracaso en el proceso de aprendizaje. El plagio deliberado es un comportamiento poco ético y puede comportar graves consecuencias para tu futura carrera profesional; a la vez que quiebra las bases de la institución y de los estudios en los que tiene lugar (2012: 364).

\section{Método de investigación}

La investigación es de carácter descriptivo, basada en la revisión bibliográfica, la observación transversal y el análisis documental de las resoluciones emitidas por la Sala de Propiedad Intelectual del Tribunal de Indecopi en el Perú, que constituyen jurisprudencia en materia de propiedad intelectual, para finalmente cuantificar en una tabla de frecuencias la incidencia porcentual de cada una de las variables e indicadores objeto de la investigación.

- Las fuentes de datos utilizadas fueron bibliográficas y documentales impresas: libros, tesis, material de referencia, artículos en publicaciones periódicas, boletines, etcétera.

- Fuentes electrónicas. La principal fuente de información fue la de carácter oficial, resoluciones del Tribunal de Indecopi, las mismas que se encuentran en la página web de la institución. A la vez, Internet posibilitó el acceso a la información, tanto de carácter nacional como internacional, de organismos públicos, privados y organismos no gubernamentales, entre otros. Estas fuentes estuvieron constituidas por publicaciones oficiales, ensayos, artículos de revistas en texto completo y bases de datos.

- Recolección de datos. Se realizó un estudio analítico e interpretativo de las resoluciones emitidas por la Sala de Propiedad Intelectual de Indecopi, publicadas en la página web de la institución, sobre la infracción a los derechos morales del autor. Para cuyo efecto se elaboró un instrumento ad hoc, una tabla de doble entrada en la que se consignaron los datos que respondían a cada uno de los indicadores.

- Ámbito temporal. El periodo del estudio correspondió a los años 2008 al 2011, respecto a los expedientes sobre infracción a los derechos morales 
del autor, en particular los referidos al derecho de paternidad.

- Unidades de análisis. Cada una de las resoluciones expedidas por la Sala de la Propiedad Intelectual del Tribunal de Indecopi.

- Unidad Impositiva Tributaria (UIT). Es un valor de referencia para todo tipo de impuestos. Se aplica también para establecer sanciones y demás obligaciones contables. El Ministerio de Economía y Finanzas es el encargado de fijar anualmente el monto de esta unidad.

- Tratamiento y análisis de datos. Luego de la identificación de los expedientes sobre la materia de interés, se procedió a resumirlos con base en la tabla de variables e indicadores establecidos previamente, para finalmente cuantificar las frecuencias y luego elaborar las tablas con apoyo del programa Excel en función a los resultados de cada uno de los indicadores y del programa Word para el informe final.

- Referentes teórico-conceptuales. Los conceptos desarrollados con base en la revisión de la literatura que sustentaron la descripción, análisis e interpretación de la información fueron: plagio, derecho de autor, derechos morales y patrimoniales del autor.

- Población y muestra. La población estuvo conformada por todos los expedientes tramitados ante la Dirección de Derecho de Autor de Indecopi, desde el 2008 a 2011, sobre infracción a los derechos morales del autor; la muestra consistió en 43 expedientes ubicados en la página web de la institución.

- Variables del estudio. Los aspectos de interés para cumplir con los objetivos propuestos se determinaron en ocho variables, cada una de ellas desagregadas en sus respectivos indicadores, tal como se muestra en la tabla siguiente:

Tabla 3. Variables e indicadores.

\begin{tabular}{|c|c|}
\hline Variables & Indicadores \\
\hline $\begin{array}{l}\text { 1. Materia de la denuncia (afectación a } \\
\text { los derechos morales del autor) }\end{array}$ & $\begin{array}{l}\text { - Paternidad } \\
\text { - Integridad } \\
\cdot \text { Modificación } \\
\text { - Divulgación }\end{array}$ \\
\hline 2. Tipo de plagio & \begin{tabular}{|l} 
- Plagio inteligente \\
- Plagio servil
\end{tabular} \\
\hline 3. Tipo de denuncia & $\begin{array}{l}\text { - Denuncia de oficio } \\
\text { - Denuncia de parte }\end{array}$ \\
\hline 4. Tipo de obra objeto de la denuncia & $\begin{array}{l}\text { - Texto literario } \\
\text { - Enciclopedias } \\
\text { - Proyectos } \\
\text { - Tesis }\end{array}$ \\
\hline
\end{tabular}




\begin{tabular}{|c|c|}
\hline 5. Número de autores denunciados & $\begin{array}{l}\cdot \text { Un autor } \\
\text { - Varios autores } \\
\text { - Autores corporativos }\end{array}$ \\
\hline $\begin{array}{l}\text { 6. Sanción en primera instancia } \\
\text { (Dirección de Derecho de Autor) }\end{array}$ & $\begin{array}{l}\text { - Multa más de } 5 \text { UIT } \\
\text { - Multa menos de } 5 \text { UIT } \\
\text { - Denuncia ante el Ministerio Público }\end{array}$ \\
\hline $\begin{array}{l}\text { 7. Fallo en segunda instancia } \\
\text { (Sala de Propiedad Intelectual) }\end{array}$ & $\begin{array}{l}\text { - Rebajar la multa } \\
\text { - Denuncia al Ministerio Público }\end{array}$ \\
\hline 8. Justificación & $\begin{array}{l}\text { - Considera un error } \\
\text { - No acepta los cargos } \\
\text { - Desconoce la forma de citar }\end{array}$ \\
\hline
\end{tabular}

\section{Resultados}

Previamente a la descripción y análisis de los datos es importante conocer las definiciones conceptuales de los indicadores analizados en el estudio, las cuales están contenidas en la doctrina y en el Decreto Legislativo Núm. 822, norma jurídica aprobada en el Perú que protege los derechos de autor.

- Denuncia de oficio. La propia entidad administrativa o judicial, en cumplimiento de sus atribuciones establecidas por ley, entabla la denuncia por considerar que se ha infringido la norma.

- Denuncia de parte. El autor o sus causahabientes denuncian el hecho por afectación a sus derechos.

- Denuncia improcedente. Se produce cuando no se cumple con los requisitos de fondo al interponer la denuncia.

- Derecho de paternidad. Por éste el autor tiene el derecho de ser reconocido como tal, de determinar que la obra lleve las indicaciones correspondientes y de resolver si la divulgación ha de hacerse con su nombre, bajo seudónimo o signo, o en forma anónima (Dec. Leg. Núm. 822 Art. 24.).

- Divulgación. Por el derecho de divulgación, corresponde al autor la facultad de decidir si su obra ha de ser divulgada y en qué forma. En el caso de mantenerse inédita, el autor podrá disponer, por testamento o por otra manifestación escrita de su voluntad, que la obra no sea publicada mientras esté en el dominio privado [...] (Dec. Leg. Núm. 822 Art. $\left.23^{\circ}\right)$.

- Integridad. Por el derecho de integridad, el autor tiene, incluso frente al adquirente del objeto material que contiene la obra, la facultad de oponerse a toda deformación, modificación, mutilación o alteración de la misma (Dec. Leg. Núm. 822 Art. $25^{\circ}$ ). 
- Modificación. Por el derecho de modificación o variación, el autor antes o después de su divulgación tiene la facultad de modificar su obra respetando los derechos adquiridos por terceros, a quienes deberá previamente indemnizar por los daños y perjuicios que les pudiere ocasionar (Dec. Leg. Núm. 822 Art. $26^{\circ}$ ).

- Plagio inteligente. Copiar una obra, alterándola o modificándola, con palabras, frases, o párrafos, a fin de que pase inadvertida la copia literal.

- Plagio servil. Copiar parte o la totalidad de una obra textualmente, sin mayores modificaciones, de tal forma que es muy fácil distinguir la similitud.

- Titularidad originaria. Emana de la sola creación de la obra (Dec. Leg. Núm. 822 Art. 44).

- Titularidad derivada. Surge por circunstancias distintas de la creación, sea por mandato o presunción legal, o bien por cesión mediante acto entre vivos o transmisión mortis causa (Dec. Leg. Núm. 822 Art. 45).

El Anexo 1 indica el número de cada uno de los expedientes (43 en total) y resoluciones emitidas por la Sala de Propiedad Intelectual de Indecopi entre 2008 y 2011, los que constituyen jurisprudencia en materia de propiedad intelectual en el Perú y se encuentran en la página web de la institución.

En función de las variables e indicadores de la Tabla 3, a continuación se describen los resultados de la observación y el análisis de las resoluciones (43 en total).

\section{Materia de la denuncia (afectación a los derechos morales del autor)}

Los derechos morales del autor incluyen el derecho a la paternidad, a la integridad, a la divulgación, a la modificación, el retiro de la obra del comercio y el derecho de acceso (Dec. Leg. 822 Art. 22). Como tal, un mismo infractor puede ser denunciado por infringir varios derechos morales del autor (por ejemplo, infringir el derecho de paternidad, integración y divulgación).

A partir de la revisión de todos los expedientes (43) referidos a la afectación de los derechos morales, se puede inferir que un alto porcentaje $(95 \%)$ de procesos administrativos iniciados en Indecopi entre 2008 y 2011, fueron denuncias por vulnerar la paternidad de la obra. A la par, el $19 \%$ se refiere a la afectación de la integridad y en menor número a la de divulgación, lo cual demuestra que la infracción a la paternidad de la obra, que en la gran mayoría se traduce en plagio, constituye uno de los problemas más álgidos en la protección a los derechos del autor. 
Tabla 4. Materia de la denuncia (2008-2011).

\begin{tabular}{|c|c|c|c|c|c|c|}
\hline \multirow{2}{*}{ Materia de la denuncia } & \multicolumn{4}{|c|}{ Años } & \multirow[t]{2}{*}{ Total } & \multirow[t]{2}{*}{$\%$} \\
\hline & 2008 & 2009 & 2010 & 2011 & & \\
\hline Paternidad & 13 & 6 & 9 & 13 & 41 & 95 \\
\hline Integridad & - & 4 & 3 & 1 & 8 & 19 \\
\hline Divulgación & 2 & 2 & - & 1 & 5 & 12 \\
\hline No precisa & 1 & - & - & - & 1 & 2 \\
\hline
\end{tabular}

\section{Tipo de plagio}

El plagio es la usurpación a la paternidad del autor. Las denuncias presentadas por afectación a los derechos morales de éste (derecho de paternidad) han sido expresamente tipificadas en el expediente (plagio servil y plagio inteligente). De acuerdo con los resultados obtenidos del análisis documental, se tiene que cerca de la mitad de las denuncias $(39.5 \%$ ) corresponden a la modalidad del plagio servil, y un poco más de la cuarta parte $(25.5 \%)$ al plagio inteligente, en tanto que un importante porcentaje de las resoluciones $(35 \%)$ no precisan el tipo de infracción cometida, sólo se reducen a indicar que se denuncia la afectación a los derechos morales de paternidad. Esta evidencia empírica nos muestra que los infractores recurren con mayor frecuencia al plagio servil o burdo (lo que equivale a decir "copiar y pegar" el texto ajeno) haciéndolo pasar como suyo, usurpando la paternidad del verdadero autor sin ningún tipo de consideración ética ni mucho menos de carácter legal.

Tabla 5. Tipo de plagio (2008-2011).

\begin{tabular}{|c|c|c|c|c|c|c|}
\hline \multirow[t]{2}{*}{ Tipo de plagio } & \multicolumn{4}{|c|}{ Años } & \multirow[t]{2}{*}{ Total } & \multirow[t]{2}{*}{$\%$} \\
\hline & 2008 & 2009 & 2010 & 2011 & & \\
\hline Plagio servil & 2 & 2 & 6 & 7 & 17 & 39.5 \\
\hline Plagio inteligente & 7 & 1 & 1 & 2 & 11 & 25.5 \\
\hline No especifica & 5 & 3 & 2 & 5 & 15 & 35 \\
\hline Total & 14 & 6 & 9 & 14 & 43 & 100 \\
\hline
\end{tabular}

\section{Tipo de denuncia}

Las denuncias administrativas ante Indecopi pueden formalizarse bajo dos modalidades: la denuncia de oficio, cuando la propia entidad que protege los 
derechos de autor, al evaluar minuciosamente el contenido de la obra, antes de otorgar el certificado de registro, detecta la infracción a la ley; y la denuncia de parte, cuando el autor o sus causahabientes denuncian la vulneración a sus derechos. Con respecto a esta variable, los resultados muestran que más de la mitad de los procesos (67\%) fueron denuncias formuladas de oficio, en tanto que sólo el 33 \% se inició por acción directa de los afectados. Esto indica que la vulneración a los derechos morales del autor la mayoría de las veces es detectada durante el proceso de calificación, tras la solicitud del registro de una obra a la Dirección de Derecho de Autor de Indecopi. Este resultado denota el grave problema moral de los solicitantes, quienes a sabiendas de que en la elaboración de sus obras han infringido los derechos morales del autor, tratan de sorprender a las autoridades solicitando su registro.

Tabla 6. Tipo de denuncia (2008-2011).

\begin{tabular}{|c|c|c|c|c|c|c|}
\hline \multirow[t]{2}{*}{ Tipo de denuncia } & \multicolumn{4}{|c|}{ Años } & \multirow[t]{2}{*}{ Total } & \multirow[t]{2}{*}{$\%$} \\
\hline & 2008 & 2009 & 2010 & 2011 & & \\
\hline Denuncia de oficio & 10 & 4 & 6 & 9 & 29 & 67 \\
\hline Denuncia de parte & 4 & 2 & 3 & 5 & 14 & 33 \\
\hline Total & 14 & 6 & 9 & 14 & 43 & 100 \\
\hline
\end{tabular}

\section{Tipo de obra objeto de denuncia}

Los tipos de obras protegidas por el derecho de autor son diversas, el Dec. Leg. Núm. 822 hace mención a más de una docena, una de las cuales la conforman las obras literarias, bajo cuya denominación, para efectos del presente estudio, se han incluido los textos, enciclopedias, proyectos y tesis. Los resultados de la observación y el análisis documental indica que la gran mayoría de obras objeto de denuncia por afectación a los derechos morales del autor son textos literarios ( $86 \%$ ), seguido de las enciclopedias, proyectos, tesis y otros, que sumados alcanzan sólo el $14 \%$. Este resultado muestra que la mayoría de los autores que acuden a registrar sus obras elaboran textos (libros) de carácter científico, técnico o literario, siendo un número muy reducido otro tipo de obras.

Tabla 7. Tipo de obra objeto de denuncia.

\begin{tabular}{|l|c|c|c|c|c|c|}
\hline \multirow{2}{*}{ Tipo de obra } & \multicolumn{4}{|c|}{ Años } & \multirow{2}{*}{ Total } & $\%$ \\
\cline { 2 - 6 } & 2008 & 2009 & 2010 & 2011 & & \\
\hline Texto literario & 13 & 6 & 7 & 11 & 37 & 86 \\
\hline Enciclopedias & 1 & - & - & - & 1 & 2.3 \\
\hline
\end{tabular}




\begin{tabular}{|l|c|c|c|c|c|c|}
\hline Proyectos & - & - & 1 & 2 & 3 & 7 \\
\hline Tesis & - & - & 1 & - & 1 & 2.3 \\
\hline Otros & - & - & - & 1 & 1 & 2.3 \\
\hline \multicolumn{1}{|c|}{ Total } & 14 & 6 & 9 & 14 & 43 & 100 \\
\hline
\end{tabular}

\section{Número de autores denunciados}

De todas las denuncias formalizadas, la mitad de ellas (51\%) corresponde a obras de un solo autor, en tanto que el $35 \%$ a varios autores, y sólo el $14 \%$ a autores corporativos, sean éstos editoriales, municipalidades o instituciones del Estado. Lo cual indica que la creación y elaboración de textos literarios es, mayoritariamente, el esfuerzo de un solo autor, y deja de lado la colaboración de coautores.

Tabla 8. Número de autores denunciados.

\begin{tabular}{|l|c|c|c|c|c|c|}
\hline \multirow{2}{*}{ Núm. de autores denunciados } & \multicolumn{4}{|c|}{ Años } & \multirow{2}{*}{ Total } & \multirow{2}{*}{$\%$} \\
\cline { 2 - 6 } & 2008 & 2009 & 2010 & 2011 & & \\
\hline Un autor & 6 & 4 & 4 & 8 & 22 & 51 \\
\hline Varios autores & 7 & 2 & 4 & 2 & 15 & 35 \\
\hline Autor corporativo & 1 & - & 1 & 4 & 6 & 14 \\
\hline \multicolumn{1}{|c|}{ Total } & 14 & 6 & 9 & 14 & 43 & 100 \\
\hline
\end{tabular}

\section{Sanción en primera instancia (Dirección de Derecho de Autor)}

El procedimiento administrativo sancionador es el medio del que se vale el Indecopi, a través de la Dirección de Derecho de Autor, para imponerle una sanción al denunciado cuando admite a trámite una denuncia de parte o de oficio al detectar que éste ha infringido la ley. Las sanciones generalmente son pecuniarias (multa). Respecto a las jurisprudencias analizadas, las sanciones impuestas en esta instancia a la mayoría de los denunciados (72\%) consistieron en una multa elevada igual o mayor a las 5 UIT (más de 18,000 nuevos soles) y sólo el 7 \% recibió una multa menor a las 5 UIT. Sólo un denunciado fue sancionado con amonestación. Por otro lado, casi la mitad de los infractores (49 \%) fueron sancionados, además de la multa pecuniaria, con poner en conocimiento del Ministerio Público el acto doloso, a quien le corresponde investigar y, si los hechos lo ameritan, denunciarlos y procesarlos en el Poder Judicial, considerando que el plagio se encuentra tipificado como delito en el Código Penal vigente. 
Tabla 9. Sanción en primera instancia.

\begin{tabular}{|c|c|c|c|c|c|c|}
\hline \multirow[t]{2}{*}{ Sanción en primera instancia } & \multicolumn{4}{|c|}{ Años } & \multirow[t]{2}{*}{ Total } & \multirow[t]{2}{*}{$\%$} \\
\hline & 2008 & 2009 & 2010 & 2011 & & \\
\hline Amonestación & - & 1 & - & - & 1 & 2.3 \\
\hline Multa más de 5 UIT & 11 & 3 & 7 & 10 & 31 & 72 \\
\hline Multa menos de 5 UIT & 1 & 1 & 1 & - & 3 & 7 \\
\hline Improcedente & & $1-$ & - & 2 & 3 & 7 \\
\hline Infundada & 1 & 1 & 1 & 2 & 5 & 12 \\
\hline $\begin{array}{l}\text { Poner en conocimiento del } \\
\text { Ministerio Público }\end{array}$ & 4 & 3 & 7 & 7 & 21 & 49 \\
\hline
\end{tabular}

\section{Fallo en la segunda instancia (Tribunal de la Propiedad Intelectual)}

Una vez concluido el procedimiento administrativo sancionador en primera instancia, en vía de apelación el sancionado puede acudir al Tribunal de la segunda y última instancia (Sala de Propiedad Intelectual de Indecopi), con cuya resolución se agota el proceso administrativo. De las resoluciones revisadas, se tiene que las 43 fueron objeto de apelación, y del fallo emitido en esta instancia se tiene que a la gran mayoría de sancionados $(60 \%)$ se les rebajó la multa muy por debajo de las impuestas en primera instancia; de haber varios denunciados el pago se consideró en forma solidaria. Por otro lado, la decisión de la Sala de poner a conocimiento del Ministerio Público sólo alcanzó a un escaso porcentaje (26 \%) (11 denuncias), menos de la mitad de lo que establecía la instancia anterior.

Tabla 10. Fallo en la segunda instancia.

\begin{tabular}{|c|c|c|c|c|c|c|}
\hline \multirow[t]{2}{*}{ Fallo del Tribunal } & \multicolumn{4}{|c|}{ Años } & \multirow[t]{2}{*}{ Total } & \multirow[t]{2}{*}{$\%$} \\
\hline & 2008 & 2009 & 2010 & 2011 & & \\
\hline Confirmar la resolución & 1 & - & 2 & - & 3 & 7 \\
\hline Nulidad & - & - & 1 & - & 1 & 2.3 \\
\hline Rebajar la multa & 11 & - & 5 & 10 & 26 & 60 \\
\hline Improcedente & 1 & - & - & 1 & 2 & 5 \\
\hline Infundada & 1 & - & 1 & 3 & 5 & 12 \\
\hline $\begin{array}{l}\text { Poner a conocimiento del } \\
\text { Ministerio Público }\end{array}$ & 2 & 1 & 5 & 3 & 11 & 26 \\
\hline
\end{tabular}

\section{Justificación de los denunciados}

Una vez interpuesta y admitida la denuncia, el procedimiento administrativo sancionador faculta a los denunciados a presentar sus descargos. De todas las denuncias admitidas en primera instancia (43) se desprende que cerca de la mitad de ellos (47\%) sostuvieron explícitamente como justificación que 
tomaron e incluyeron textos ajenos en las obras cuyo registro solicitaban, y consideraron este hecho sólo como un error, por desconocimiento de los requisitos y por la falta de cuidado en la elaboración del texto. En tanto que una tercera parte $(37 \%$ ) no aceptó el cargo y negó haber cometido infracción al derecho de paternidad, no obstante que las evidencias encontradas por la autoridad eran contundentes. De lo anterior se desprende que los autores que crean o elaboran un texto minimizan la infracción al derecho de autor y desconocen así la propiedad ajena.

Tabla 11. Justificación.

\begin{tabular}{|c|c|c|c|c|c|c|}
\hline \multirow[t]{2}{*}{ Justificación } & \multicolumn{4}{|c|}{ Años } & \multirow[t]{2}{*}{ Total } & \multirow[t]{2}{*}{$\%$} \\
\hline & 2008 & 2009 & 2010 & 2011 & & \\
\hline Consideran un error & 11 & - & 3 & 6 & 20 & 47 \\
\hline No aceptan el cargo & 1 & 5 & 5 & 5 & 16 & 37 \\
\hline $\begin{array}{l}\text { Desconocimiento del } \\
\text { derecho de cita }\end{array}$ & - & - & 1 & 3 & 4 & 9 \\
\hline No hubo justificación & 2 & 1 & - & - & 3 & 7 \\
\hline Total & 14 & 6 & 9 & 14 & 43 & 100 \\
\hline
\end{tabular}

\section{Discusión}

La propiedad intelectual es el derecho que tienen los autores, creadores o inventores sobre la obra fruto de su creación. De acuerdo con la Organización Mundial de la Propiedad Intelectual, las ramas de la propiedad intelectual son dos, el derecho de autor y la propiedad industrial, los cuales son protegidos por el Estado peruano a través de Indecopi. El derecho de autor "Es la rama del derecho que regula los derechos subjetivos del autor sobre las creaciones que presentan resultantes de su actividad intelectual que habitualmente son enunciadas como obras literarias, musicales, teatrales, artísticas, científicas y audiovisuales" (Cruz, 2007: 2). "El autor de una obra tiene por el solo hecho de la creación la titularidad originaria de un derecho exclusivo y oponible a terceros, que comprende, a su vez, los derechos de orden moral y patrimonial determinados en la presente ley" (Dec. Leg. Núm. 822 Art. 18). Este derecho forma parte de los derechos fundamentales de las personas, plasmados en convenios y normas de carácter internacional que el Perú ha suscrito. A nivel nacional se cuenta con una amplia legislación que tutela estos derechos, que van desde el Art. 2 de la Constitución -"Toda persona tiene derecho: [...] 8. A la libertad de creación intelectual, artística, técnica y científica, así como a la propiedad sobre dichas creaciones y a su producto. El Estado propicia el 
acceso a la cultura y fomenta su desarrollo y difusión"- hasta las de menor jerarquía, sean éstas leyes, decretos legislativos, decretos supremos u otros.

El objetivo de la investigación es identificar y analizar un conjunto de resoluciones (43) dictadas por el Tribunal de Propiedad Intelectual de Indecopi en Perú que resuelven administrativamente en última instancia las denuncias sobre infracción a los derechos morales del autor, las cuales pueden ser: a) El derecho de divulgación. b) El derecho de paternidad. c) El derecho de integridad. d) El derecho de modificación o variación. e) El derecho de retiro de la obra del comercio y f) El derecho de acceso (Dec. Leg. Núm. 822 Art. 22). Estas resoluciones constituyen jurisprudencia administrativa y se producen durante el procedimiento administrativo sancionador que tienen a su cargo los órganos competentes del Indecopi, los que resuelven las causas en dos instancias. En la primera, la Dirección de Derecho de Autor "Es responsable de proteger los derechos de autor y los derechos conexos. Resuelve en primera instancia las causas contenciosas y no contenciosas que son sometidas a su jurisdicción, por denuncia de parte o de oficio. Administra el Registro Nacional de Derecho de Autor y Derechos Conexos [...]" (http://www.indecopi.gob. pe). En la segunda y última instancia, "La Sala de la Propiedad Intelectual es el órgano funcional que resuelve en apelación los procesos seguidos ante las Direcciones de Signos Distintivos, Invenciones y Nuevas Tecnologías y de Derecho de Autor del Indecopi" (http://www.indecopi.gob.pe). Con su resolución se agota la vía administrativa.

Cabe señalar que no obstante que el bien jurídico protegido por el derecho de autor es la propiedad intelectual de autores e inventores, la afectación a los derechos de paternidad de la obra a través de la figura del plagio se hace cada vez más extendida, particularmente en el ámbito académico, influenciada por las nuevas tecnologías de la información y las comunicaciones que ponen a disposición ingentes cantidades de datos e información; y también por el uso de programas informáticos que facilitan el "copiar y pegar". Al respecto, es ilustrativa la conclusión a la que llegaron los investigadores Saldaña, Quezada, Peña y Mayta, quienes revisaron y analizaron "[...] el total de tesis para optar el Título de Médico Cirujano durante el año 2008 en una universidad pública peruana" (2010: 64) y encontraron una alta frecuencia de plagio, siendo el más frecuente el plagio literal (llamado también plagio servil). Sin embargo, es evidente el escaso número de denuncias administrativas que se interponen ante la entidad responsable de proteger la propiedad intelectual (Indecopi), cuya función se limita, la mayoría de las veces, a formalizar denuncias de oficio producto de la revisión de una obra en la etapa del registro. Como tales, los procesos contencioso-administrativos seguidos ante la entidad estatal no reflejan la complejidad del problema, en tanto que 
es evidente la manifiesta inoperancia de las instituciones de educación superior, que hacen poco o nada para normar al respecto, y también son pocos los centros de educación superior que han reglamentado y sancionado este tipo de conductas deshonestas. En el ámbito del Poder Judicial, no obstante que el plagio es una figura delictiva sancionada con pena privativa de la libertad, es casi nula la persecución y sanción a esta clase de delitos.

Para efectos de la presente investigación, se analizó el contenido de 43 resoluciones emitidas entre 2008 y 2011 por la Sala de Propiedad Intelectual de Indecopi relativas a la infracción a los derechos morales del autor, identificando ocho variables y sus respectivos indicadores. De los datos recogidos durante el periodo de análisis documental y la posterior tabulación, se puede advertir que casi la totalidad de los casos sancionados corresponden a la infracción al derecho de paternidad de la obra, que "Es el derecho que tiene el autor a que se reconozca la obra como suya y a vincular o no su nombre a ella. El autor puede comunicar su obra al público con su propio nombre, con un nombre ficticio (seudónimo) o de manera anónima" (Martínez y Robayo, 2006: 11). Tal infracción se manifiesta en el hurto o robo del contenido de las obras ajenas, que la doctrina denomina plagio. Lipszyc (1993) lo clasifica como plagio burdo o servil y plagio inteligente, clasificación más usada en la fundamentación de las resoluciones de Indecopi. Es así que la mayoría de las denuncias formuladas ante Indecopi han sido por plagio burdo o servil, hecho que evidencia el poco respeto que se le tiene al derecho de autor, que es un derecho intangible con mayor componente ético y moral que delictivo.

Sobre los tipos de denuncias en el procedimiento administrativo, éstas pueden ser formalizadas bajo dos modalidades: la denuncia de oficio y a instancia de parte. El primer caso se produce cuando la autoridad competente (Dirección de Derecho de Autor de Indecopi) conoce el hecho en la etapa de calificación del registro de una obra, y al encontrar suficientes elementos o indicios de infracción a la ley interpone la respectiva denuncia. Y a instancia de parte, el hecho se formaliza cuando el afectado o sus causahabientes denuncian a los presuntos responsables de vulnerar los derechos morales o patrimoniales del autor. Los datos muestran que un alto porcentaje de las denuncias se origina de oficio como parte de las funciones que ejerce la Dirección de Derechos de Autor.

Dado que las obras protegidas son de varios tipos, el estudio ha centrado su atención sólo en las obras literarias, entendidas como: "Toda creación intelectual, sea de carácter literario, científico, técnico o meramente práctico, expresada mediante un lenguaje determinado" (Dec. Leg. Núm. 822 Art. 2.23). En dicha categoría se ha considerado a los textos literarios, enciclopedias, proyectos y tesis, de los cuales la mayoría de las obras objeto de la denuncia por infracción a los derechos morales del autor son textos literarios. 
Sobre el tipo de sanciones impuestas en última instancia por el Tribunal de Indecopi, éstas han sido muy benignas si comparamos con lo que dispone el Decreto Legislativo Núm. 822 en su Art. 188: "La Oficina de Derechos de Autor podrá imponer conjunta o indistintamente, las siguientes sanciones: inc. b) Multa de hasta 150 Unidades Impositivas Tributarias" (la UIT equivale a 3,750.00 nuevos soles. Esta multa es una sanción pecuniaria muy alta; sin embargo, las resoluciones emitidas por el Tribunal muestran que a la gran mayoría de los sancionados se les rebajan las multas a cifras mucho menores a las impuestas en primera instancia. Por tanto, es poco lo que se puede hacer para frenar el grave problema moral y legal del plagio y la afectación a los derechos morales del autor. Cabe notar que las decisiones adoptadas por la Sala son controversiales, toda vez que el Tribunal actúa con complacencia frente a la infracción a los derechos morales del autor. Asimismo, la ley faculta: "Presentar, si lo considera pertinente, denuncia penal, cuando tenga conocimiento de un hecho que constituya presunto Delito" (Dec. Leg. Núm. 822 Art. 169.c). Y lo más inexplicable es que son pocas las sanciones que impliquen poner el hecho a conocimiento del Ministerio Público, por considerarlos sólo una infracción administrativa; con lo cual dejan de constituir un delito, con la consecuente impunidad de la acción delictiva.

Respecto a la justificación que presentan los denunciados en la etapa de descargo, la mayoría considera que ha cometido un error y no una infracción, mucho menos un delito. Este tipo de justificaciones no son más que el reflejo de lo que pasa en el imaginario colectivo respecto a la protección de la propiedad intelectual; se minimiza el respeto a la creación ajena con las frases que se suelen emplear: "Nibil novum sub solem -'No hay nada nuevo bajo el sol', Eclesiastés (I, 10) - [...] Nullum est jam dictum, quod (non) dictum sit prius (no haya nada que no haya sido dicho antes, Prólogo del Eunuco) [...]” (citado por Perromat, 2010: 13).

Esto les exige a las instituciones encargadas de tutelar la propiedad intelectual sanciones más drásticas y una labor permanente de difusión de la norma, buscando que la sociedad internalice la importancia de la labor intelectual de los autores y creadores, condición básica de desarrollo para el país.

[...] debe tenerse en consideración que el derecho de autor es el que permite a los creadores (escritores, científicos, pintores, escultores, poetas, programadores de software, directores, etc.) tener los incentivos para seguir creando y dicho proceso creativo es indispensable para el desarrollo del país [...]. En efecto, en aquellos países en los que existe un sistema de protección efectiva del derecho de autor y, adicionalmente, se ha logrado instaurar una cultura de respeto de dichos derechos en la sociedad, el derecho de autor deja de ser un obstáculo, pasa a ser considerado 
como un mecanismo necesario que hace posible el acceso a la cultura y contribuye a crear una identidad social-con educación-para el progreso (Kresalja, Marticorena, Roca y Unger, 2007: 69).

\section{Conclusiones}

En función de los objetivos planteados para la investigación sobre el rol de Indecopi frente a denuncias de infracción a la propiedad intelectual y sobre las sanciones impuestas por este organismo, se llegó a las conclusiones siguientes.

- Se advierte que de la totalidad de los expedientes (43) objeto del procedimiento administrativo sancionador por afectar los derechos morales del autor, la mayoría de los casos $(95 \%)$ son denuncias por vulnerar la paternidad del autor en la modalidad de plagio burdo o servil (39.5\%), es decir, la copia literal sin modificación alguna, sustituyendo así la paternidad de la obra, lo cual denota astucia e intencionalidad del plagiario que toma en su integridad el contenido de una obra literaria, básicamente sin citar la fuente ni darle crédito al autor.

- De los expedientes analizados, la gran mayoría de ellos (67\%) se iniciaron por denuncias de oficio, luego que el autor solicitara el registro de su obra. Solicitar el registro de una obra no significa que a partir de ella se pida el reconocimiento del derecho de autor. Por formar parte de los derechos humanos, éste existe de manera automática sin requerir de formalidad alguna, lo que hace el autor es probar que la obra es fruto de su creación y el registro, sólo le sirve como publicidad y prueba de anterioridad.

- Sobre el tipo de obras protegidas, un alto porcentaje (86 \%) corresponde a textos literarios, elaborados en su mayoría ( $51 \%$ ) por un solo autor, lo que indica que la elaboración de un texto corresponde mayoritariamente a la acción de una sola persona, quien escribe con un fin determinado, sea para una investigación académica, o con fines de instrucción o entretenimiento, pero para ello hurta o roba el contenido de obras ajenas de manera literal o con algunas alteraciones intencionales, a fin de que éstas pasen inadvertidas, para luego solicitar el registro a sabiendas de que el contenido total o parcial no es producto de su creación, y desconociendo o minimizando la labor de control, calificación y revisión que realiza la Dirección de Derechos de Autor actúa con absoluta falta de moral, que no es más que el reflejo de la profunda crisis de valores en nuestra sociedad. 
- En cuanto a las sanciones que Indecopi impone al comprobar la infracción al derecho de autor, la ley faculta entre otras: a) Amonestación; b) Multa de hasta 180 Unidades Impositivas Tributarias. De las resoluciones revisadas se desprende que en primera instancia, cerca de las tres cuartas partes de los denunciados $(72 \%)$ fueron sancionados con multas mayores o iguales a las 5 UIT (más de 18,000 nuevos soles). Sin embargo, en el proceso de apelación a la segunda instancia, a más de la mitad de ellos (60 \%) la Sala de Propiedad Intelectual les rebajó la multa muy por debajo de 5 UIT, multa que en la práctica no suele pagarse debido a los insuficientes mecanismos que obligan a su cumplimiento.

- Los casos resueltos en primera instancia que disponen, además de la sanción pecuniaria, poner éstos en conocimiento del Ministerio Público (para evaluar la denuncia penal por constituir un delito) representan porcentualmente casi la mitad (49\%) de los procesados. Sin embargo, luego de la apelación, las resoluciones muestran que la Sala dejó sin efecto la sanción o redujo éstas a cifras poco significativas, el $26 \%$ del total de los denunciados, lo que denota permisividad y tolerancia hacia la vulneración al derecho de autor.

- Sobre la justificación que presentaron los denunciados en la etapa de descargo, cerca de la mitad, el $47 \%$, aceptó haber incurrido en infracción a la ley; sin embargo, calificaron tal conducta como un simple error, descuido o desconocimiento de los requisitos previos a la solicitud del registro de la obra, en tanto que algunos expresamente se pusieron como víctimas argumentando que el Indecopi también tenía cierto grado de responsabilidad al no realizar una revisión previa antes de haber iniciado los trámites. La tercera parte (37 \%) señaló explícitamente que no aceptaba haber infringido el derecho de autor y algunos justificaban su conducta, aduciendo el desconocimiento del derecho de cita.

- Finalmente es menester señalar que el rol del Instituto de Defensa de la Competencia y de la Propiedad Intelectual carece de eficacia, dados los resultados de la revisión y análisis de las resoluciones emitidas por el Tribunal, tanto en la primera como en la segunda instancia.

\section{REFERENCIAS BIBLIOGRÁFICAS}

Alva M., Fernando (2009), Sistema de información de detección de plagio en documentos digitales usando el método Document Fingerprinting, tesis de título de Ingeniero Informático, Facultad de Ciencias e Ingeniería, Pontificia Universidad Católica del Perú, Lima, Perú. 
Antequera, R. y Ferreyros, M. (1996), El nuevo derecho de autor en el Perú, Lima: Ed. Monterrico.

Astudillo, F. (2006), "El plagio intelectual", en Revista Propiedad Intelectual, 5 (8-9), Universidad de los Andes (Venezuela), Facultad de Ciencias Jurídicas y Políticas, pp. 242-270.

Balbuena, P. (s. a.), "El plagio como ilícito penal", en Ventana Legal Revista, disponible en: www.ventanalegal.com/revista_ventanalegal /plagio_ilicito.htm [Consultado: 13 de agosto de 2012].

Busta, F. (1997), El derecho de autor en el Perú, t. 1, Lima: Grijley.

Cabanellas, G. (1976), Diccionario de derecho usual, Buenos Aires: Heliasta.

Cabedo, A. (2010), "Recursos informáticos para la detección del plagio académico", en Tejuelo, 8, pp. 8-26, disponible en: http://iesgt ballester.juntaextremadura.net/web/profesores/tejuelo/vinculos/ articulos/r08/02.pdf [Consultado: 12 de junio de 2012].

Carmona, C. (1988), La nueva ley de propiedad intelectual, Madrid: Montecorbo.

Castillo, J. (2012), Payola. Derecho e industria musical, Santo Domingo: Ediciones Ferlibro.

Cavanillas, S. (2008), "El ciberplagio en la normativa universitaria", en Digithum, 10, pp. 1-6, disponible en: http://redalyc.uaemex. $\mathrm{mx} / \mathrm{src} /$ inicio/ArPdfRed.jp?/Cve=55001006 [Consultado: $16 \mathrm{de}$ julio de 2012].

Cerezo, H. (2006), "Aspectos éticos del plagio académico de los estudiantes", en Elementos: Ciencia y Cultura, 13 (61), p. 31, disponible en: http://www.elementos.buap.mx/num61/htm/31.htm [Consultado: 20 de agosto de 2012].

Código Penal (2007), Lima: Jurista Editores.

Código Civil (2008), Lima: Jurista Editores.

Comas, R.; Sureda, J.; Casero, A. y Morey, M. (2011), "La integridad académica entre el alumnado universitario español [resumen]", en Estudios Pedagógicos, 37 (1), pp. 207-225, disponible en: http:// www.scielo.cl/scielo.php?pid=S0718-07052011000100011\&script =sci_abstract [Consultado: 14 de julio de 2012].

Constitución Política del Perú de 1993 (1998), ed. oficial, Lima: Ministerio de Justicia.

Convenio de Berna (1886), disponible en: http://www.wipo.int/treaties/es/ip/berne/trtdocs_wo001.html [Consultado: 22 de mayo de 2012].

Cruz, I. (2007), La ética y la propiedad intelectual en la empresa cubana, disponible en: http://www.gestiopolis.com/administracion-estrate gica/etica-y-la-propiedad-intelectual.htm

Decisión Núm. 351 de la Comunidad Andina de Naciones. Régimen Común sobre Derecho de Autor y Derechos Conexos (1993), disponible en: http://andina.vlex.com/vid/regimen-derecho-autor-de rechos-conexos-32936811 [Consultado: 23 de mayo de 2012]. 
Declaración Universal de los Derechos Humanos (1948), disponible en: http://www.un.org/es/documents/udhr/index_print.shtml [Consultado: 18 de junio de 2012].

Decreto Legislativo Núm. 822. Ley Sobre el Derecho de Autor, disponible en: http://www.gob.pe/repositorioaps/0/9/par/leyesdda/dl 822.pdf [Consultado: 4 de agosto de 2012].

Delgado, A. (1988), Panorama de la protección civil y penal en materia de propiedad intelectual, Madrid: Civitas.

Domínguez, M. (2012), "Lucha contra el plagio desde las bibliotecas universitarias", en El Profesional de la Información, 21 (5), pp. 498503, disponible en: http://www.elprofesionaldelainformacion. com/contenidos/2012/septiembre/08.html [Consultado: 16 de julio de 2012].

Gaffoglio, G. (s. a.), "El plagio", en La Ley, disponible en: http://www. justiniano.com/revista_doctrina/Gafoglio/el_plagio.htm [consultado: 22 de junio de 2012].

Girón, S. (2008), Anotaciones sobre el plagio, Bogotá: Universidad Sergio Arboleda, Escuela de Política y Relaciones Internacionales.

Guinchat, C. y Menou, M. (1992), Introducción general a las ciencias y técnicas de la información y documentación, Madrid: CINCOD (CSIC)/Unesco.

Gutiérrez, A. y Montes de Oca, R. (2004), "La importancia de la lectura y su problemática en el contexto educativo universitario. El caso de la Universidad Juárez Autónoma de Tabasco (México)", en Revista Iberoamericana de Educación, disponible en: http:// www.rieoei.org/deloslectores/632Gutierrez.PDF [Consultado: 12 de septiembre de 2012].

Indecopi, Resolución Núm. 286-1998-TPI-INDECOPI, disponible en: http://systems.indecopi.gob.pe/buscResolucion/index.seam [Consultado: 16 de junio de 2012].

Indecopi, Resolución Núm. 0355-2007/ODA-INDECOPI, disponible en: http://systems.gob.pe/buscResolucion/index.seam [Consultado: 18 de julio de 2012].

Indecopi, Resolución Núm. 0207-2008/TPI-INDECOPI, Expediente Núm. 555-2007/oda, disponible en: http://systems.gob.pe/busc Resolucion/index.seam [Consultado: 16 de junio de 2012].

Indecopi, Resolución Núm. 1266-2008/TPI-, disponible en: http:// systems.gob.pe/buscResolucion/index.seam [Consultado: 16 de junio de 2012].

Indecopi, Resolución Núm. 2855-2010/TPI-, disponible en: http://sys tems.gob.pe/buscResolucion/index.seam [Consultado: 14 de agosto de 2012].

Kresalja, B.; Marticorena, B.; Roca, S. y Unger, T. (2007), "Perú, los intereses nacionales en la propiedad intelectual y los tratados de libre comercio", en S. Roca (comp.), Propiedad intelectual y comercio en el Perú. Impacto y agenda pendiente, Lima: Universidad ESAN, pp. 47-100. 
López, M. y Barquín, L. (2007), Ética y valores I, México: Trillas.

Lipszyc, D. (1993), Derecho de autor y derechos conexos, Buenos Aires: Cerlalc, Zavalía.

Martínez, R. y Robayo, E. (2006), Lo que usted debe saber sobre el derecho de autor, Bogotá: Universidad de La Sabana.

Morató, Y. (2012), "Una reflexión necesaria sobre el plagio en el EEES", en Revista UPO Innvova, 1, pp. 361-363, disponible en: http:// www.upo.es/revistas/index.php/upoinnova/articleview/113/108, [Consultado: 22 de agosto de 2012].

Organización Mundial de la Propiedad Intelectual OMPI (1988), Glosario de derecho de autor y derechos conexos, Ginebra: OMPI.

— (s. a.), Principios básicos del derecho de autor y los derechos conexos, disponible en: http://www.wipo.int/export/sites/www/freepu blications/es/intproperty/909/wipo_pub_909.pdf [Consultado: 23 de septiembre de 2012].

Pastor, C. (2009), "La Facultad de Ciencias Contables de la Universidad Nacional Mayor de San Marcos ante el ciber-plagio", en Quipukamayoc. Revista del Instituto de Investigación de la Facultad de Ciencias Contables, 16 (32), pp. 103-113, disponible en: http://in vestigacion.contabilidad.unmsm.edu.pe/revista/quipu2009-I.pdf [Consultado: 18 de mayo de 2012].

Perromat, K. (2010), El plagio en las literaturas hispánicas: historia, teoría y práctica, tesis doctoral, París: Universidad de La Sorbona, disponible en: http://www.elplagio.com/Plagio/recursos/Estruc tura/pdf [Consultado: 18 de mayo de 2012].

Polo, M. (2001), Ética. Modo de vida, comunidad y ecología, Lima: Mantaro.

Pontificia Universidad Católica del Perú, Reglamento disciplinario aplicable a los alumnos ordinarios de la PUCP, disponible en: http:// blog.pucp.edu.pe/media/1876/20080418-Microsoft\%20Word\%20 -\%2005-0003\%20Reglamento\%20disciplinario\%20aplicables \%20a \%20los\%20alumnos\%20ordinarios.pdf [Consultado: 2 de julio de 2012].

— Vice Rectorado Académico, Por qué y cómo debemos combatir el plagio, disponible en: http://www.pucp.edu.pe/documento/pucp/ plagio.pdf [Consultado: 24 de mayo de 2012].

Quiroz, R. (2003), La infracción al derecho de autor y el rol de Indecopi en su prevención, tesis doctoral, Lima, Perú: Facultad de Derecho y Ciencia Política, Universidad Nacional Mayor de San Marcos.

Real Academia Española (2001), Diccionario de la Lengua Española, $22^{a}$ ed., Madrid: Artes Gráficas.

Rojas, M., y Olarte, M. (2010), "Plagio en el ámbito académico", en Revista Colombiana de Anestesiología, 38 (4), pp. 537-538, disponible en: http://www.scielo.org.co/pdf/rca/v38n4/v38n4a10.pdf [Consultado: 4 de julio de 2012]. 
Saldaña, J.; Quezada, C.; Peña, A. y Mayta, P. (2010), “Alta frecuencia de plagio en tesis de medicina de una universidad pública peruana”, en Revista Peruana de Medicina Experimental y Salud Pública, 27 (1), pp. 63-67, disponible en: http://www.scielo.org.pe/pdf/ rins/v27n1/a11v27n1.pdf [Consultado: 8 de mayo de 2012].

Soto, A. (2012), "El plagio y su impacto a nivel académico y profesional", en E-Ciencias de la Información, 2 (1), pp. 1-13, disponible en: http://revistaebci.ucr.ac.cr/volumenes/2/2-1/2-1-2/2-1-2.pdf [Consultado: 23 de junio de 2012].

Sureda, J.; Comas, R. y Morey, M. (2009), "Las causas del plagio académico entre el alumnado universitario según el profesorado”, en Revista Iberoamericana de Educación, 50, pp. 197-220, disponible en: http://redalyc.uaemex.mx/src/inicio/ArtPdfRed.jsp?iCve $=800$ 11741011 [consultado: 20 de mayo de 2012].

Téllez, J. (2009), Derecho informático, México: McGraw-Hill.

Universidad Nacional Mayor de San Marcos (2012), Reglamento de Proceso Disciplinario para estudiantes, Lima: UNMSM.

Universidad Autónoma del Estado de Morelos. Cuerpo Académico de Ética (2002), Cómo tratar el plagio, disponible en: www://ftp. espe.edu.ec/GuiasMED/MGP2P/PROCESOS/estudiantes/C\%C3\% B3mo\%20tratar\%20el\%20plagio.pdf [Consultado: 22 de junio de 2012].

Vargas Llosa, M. (2012), "La identidad perdida", en La República. Domingo, 21 de octubre, p. 11.

Vexler, I. (2005), "Introducción", Plan Nacional de Educación Para Todos 2005-2015, Perú, Ministerio de Educación, Foro Nacional de Educación Para Todos, disponible en: http://www.minedu.gob. pe/educacionparatodos/xtras/PlanNacionalEPT2005-2015Peru 01.pdf [Consultado: 20 de julio de 2012]. 
SANCIÓN AL PLAGIO DE OBRAS LITERARIAS...

Anexo 1

Expedientes sobre infracción a los derechos morales del autor (2008-2011)

\begin{tabular}{|c|c|c|c|}
\hline 2008 & 2009 & 2010 & 2011 \\
\hline $\begin{array}{l}\text { NÚM. 1266-2008/TPI- } \\
\text { INDECOPI } \\
\text { EX. NÚM. 81-2007/ODA }\end{array}$ & $\begin{array}{l}\text { NÚM.1134-2009/TPI- } \\
\text { EXPEDIENTE NÚM. 099- } \\
\text { 2008/0DA }\end{array}$ & $\begin{array}{l}\text { NÚM. 0569-2010/TPI- } \\
\text { EX. NÚM. 093-2009/ } \\
\text { DDA }\end{array}$ & $\begin{array}{l}\text { NÚM. 0115-2011/TPI- } \\
\text { Exp. NÚM. 2108-2009/ } \\
\text { DDA }\end{array}$ \\
\hline $\begin{array}{l}\text { NÚM. 2720-2008/ } \\
\text { TPI-INDECOPI } \\
\text { EX. NÚM. 271-2008/ } \\
\text { ODA }\end{array}$ & $\begin{array}{l}\text { NÚM. 1382-2009/TPI- } \\
\text { EXPEDIENTE NÚM. } 390 \text { - } \\
\text { 2007/ODA }\end{array}$ & $\begin{array}{l}\text { NÚM. 0570-2010/TPI- } \\
\text { EX. NÚM. 075-2009/ } \\
\text { DDA }\end{array}$ & $\begin{array}{l}\text { NÚM. 1782-2011/TPI- } \\
\text { Exp. NÚM. 390-2007/ } \\
\text { DDA }\end{array}$ \\
\hline $\begin{array}{l}\text { NÚM. 0183-2008/ } \\
\text { TPI-INDECOPI } \\
\text { EX. N } 80-2007 / 0 D A\end{array}$ & $\begin{array}{l}\text { NÚM. 2131-2009/ } \\
\text { TPI-EXPEDIENTE } \\
\text { NÚM.741-2008/0DA }\end{array}$ & $\begin{array}{l}\text { NÚM. 0601-2010/TPI- } \\
\text { EX. NÚM. 1810-2008/ } \\
\text { DDA }\end{array}$ & $\begin{array}{l}\text { NÚM. 1694-2011/TPI- } \\
\text { Exp. NÚM. 1418-2009/ } \\
\text { DDA }\end{array}$ \\
\hline $\begin{array}{l}\text { NÚM. 0207-2008/ } \\
\text { TPI-INDECOPIEX. NÚM. } \\
\text { 555-2007/ODA }\end{array}$ & $\begin{array}{l}\text { NÚM. 2345-2009/ } \\
\text { TPI-EXPEDIENTE NÚM. } \\
\text { 565-2008/ODA }\end{array}$ & $\begin{array}{l}\text { NÚM. 1417-2010/TPI- } \\
\text { EX. NÚM. 450-2009/ } \\
\text { DDA }\end{array}$ & $\begin{array}{l}\text { NÚM.1506-2011 /TPI- } \\
\text { Exp. NÚM.125-2010/ } \\
\text { DDA }\end{array}$ \\
\hline $\begin{array}{l}\text { NÚM. 1121-2008/ } \\
\text { TPI-INDECOPI } \\
\text { EX. NÚM. 1538-2006/ } \\
\text { ODA }\end{array}$ & $\begin{array}{l}\text { NÚM. 3002-2009/ } \\
\text { TPI-EXPEDIENTE NÚM. } \\
\text { 079-2009/DDA }\end{array}$ & $\begin{array}{l}\text { NÚM. 2824-2010/TPI- } \\
\text { EX. NÚM. 110-2010/ } \\
\text { DDA }\end{array}$ & $\begin{array}{l}\text { NÚM.1285-2011/TPI- } \\
\text { Exp. NÚM.1616-2010 } \\
\text { /DDA }\end{array}$ \\
\hline $\begin{array}{l}\text { NÚM. 1341-2008/ } \\
\text { TPI-INDECOPI } \\
\text { EX. NÚM. 709-2007/ } \\
\text { ODA }\end{array}$ & $\begin{array}{l}\text { NÚM. 3459-2009/ } \\
\text { TPI-EXPEDIENTE NÚM. } \\
\text { 1125-2008/0DA }\end{array}$ & $\begin{array}{l}\text { NÚM. 2853-2010/TPI- } \\
\text { EX. NÚM. 1310-2009/ } \\
\text { DDA }\end{array}$ & $\begin{array}{l}\text { NÚM.1287-2011/TPI- } \\
\text { Exp. NÚM.1048-2010/ } \\
\text { DDA }\end{array}$ \\
\hline $\begin{array}{l}\text { NÚM. 1517-2008/ } \\
\text { TPI-INDECOPI } \\
\text { EX. NÚM. 345-2007/ } \\
\text { ODA }\end{array}$ & 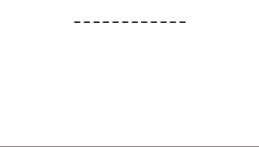 & $\begin{array}{l}\text { NÚM. 2855-2010/TPI- } \\
\text { EX. NÚM. 106-2010/ } \\
\text { DDA }\end{array}$ & $\begin{array}{l}\text { NÚM.0795-2011/TPI- } \\
\text { Exp. NÚM.2010-2009/ } \\
\text { DDA }\end{array}$ \\
\hline $\begin{array}{l}\text { NÚM. 1597-2008/ } \\
\text { TPI-INDECOPI } \\
\text { EX. NÚM. 707-2007/ } \\
\text { ODA }\end{array}$ & -------- & $\begin{array}{l}\text { NÚM. 2941-2010/TPI- } \\
\text { EX. NÚM. 1481-2008/ } \\
\text { DDA }\end{array}$ & $\begin{array}{l}\text { NÚM.0853-2011/TPI- } \\
\text { Exp. NÚM. 799-2010/ } \\
\text { DDA }\end{array}$ \\
\hline $\begin{array}{l}\text { NÚM. 0723-2008/ } \\
\text { TPI-INDECOPI } \\
\text { EX. NÚM. 1241-2005/ } \\
\text { ODA } \\
\text { Acumulado al 1590- } \\
\text { 2005/0DA }\end{array}$ & ---------- & $\begin{array}{l}\text { NÚM. 2945-2010/TPI- } \\
\text { EX. NÚM. 801-2010/ } \\
\text { DDA }\end{array}$ & $\begin{array}{l}\text { NÚM. 572-2011/TPI- } \\
\text { Exp. NÚM. 798-2010/ } \\
\text { DDA }\end{array}$ \\
\hline $\begin{array}{l}\text { NÚM. 1340-2008/ } \\
\text { TPI-INDECOPI } \\
\text { EX. NÚM. 706-2007/ } \\
\text { ODA }\end{array}$ & ----------- & ---- & $\begin{array}{l}\text { NÚM.0370-2011/TPI- } \\
\text { Exp. NÚM.111-2011/ } \\
\text { DDA }\end{array}$ \\
\hline $\begin{array}{l}\text { NÚM. 1516-2008/ } \\
\text { TPI-INDECOPI } \\
\text { EX. NÚM. 719-2007/ } \\
\text { ODA }\end{array}$ & ---------- & -------- & $\begin{array}{l}\text { NÚM.0365/TPI- } \\
\text { Exp. NÚM.1937-2009/ } \\
\text { DDA }\end{array}$ \\
\hline
\end{tabular}




\begin{tabular}{|c|c|c|c|c|}
\hline$\nabla$ & $\begin{array}{l}\text { NÚM. 2006-2008/ } \\
\text { TPI-INDECOPI } \\
\text { EX. NÚM. 1159-2007/ } \\
\text { ODA }\end{array}$ & --.----- & ---------- & $\begin{array}{l}\text { NÚM.0274 /TPI- } \\
\text { Exp. NÚM.632-2010/ } \\
\text { DDA }\end{array}$ \\
\hline & $\begin{array}{l}\text { NÚM. 2280-2008/ } \\
\text { TPI-INDECOPI } \\
\text { EX. NÚM. 321-2007/ } \\
\text { ODA }\end{array}$ & -.---.---. & --------- & $\begin{array}{l}\text { NÚM. 0209-2011/TPI- } \\
\text { Exp. NÚM. 796-2010/ } \\
\text { DDA }\end{array}$ \\
\hline & $\begin{array}{l}\text { NÚM. 2307-2008/ } \\
\text { TPI-INDECOPI } \\
\text { EX. NÚM. 960-2007/ } \\
\text { ODA }\end{array}$ & --.---- & ------ & $\begin{array}{l}\text { NÚM.0220-2011/TPI- } \\
\text { Exp. NÚM.107-2010/ } \\
\text { DDA }\end{array}$ \\
\hline & 14 & 06 & 09 & 14 \\
\hline & \multicolumn{4}{|c|}{ Total general: 43 expedientes } \\
\hline
\end{tabular}

Fuente: www.indecopi.gob.pe Elaboración propia 